\title{
Soil Atterberg limits of different weathering profiles of the collapsing gullies in the hilly granitic region of southern China
}

\author{
Yusong Deng ${ }^{1}$, Chongfa Cai ${ }^{1}$, Dong $\mathrm{Xia}^{2}$, Shuwen Ding ${ }^{1}$, Jiazhou Chen ${ }^{1}$, and Tianwei Wang ${ }^{1}$ \\ ${ }^{1}$ Key Laboratory of Arable Land Conservation (Middle and Lower Reaches of Yangtze River) of the Ministry of Agriculture, \\ College of Resources and Environment, Huazhong Agricultural University, Wuhan, 430070, People's Republic of China \\ ${ }^{2}$ College of Hydraulic and Environmental Engineering, China Three Gorges University, Yichang 443002 , \\ People's Republic of China
}

Correspondence to: Chongfa Cai (chongfacai@126.com)

Received: 7 November 2016 - Discussion started: 9 December 2016

Revised: 20 February 2017 - Accepted: 6 March 2017 - Published: 12 April 2017

\begin{abstract}
Collapsing gullies are one of the most serious soil erosion problems in the tropical and subtropical areas of southern China. However, few studies have been performed on the relationship of soil Atterberg limits with soil profiles of the collapsing gullies. Soil Atterberg limits, which include plastic limit and liquid limit, have been proposed as indicators for soil vulnerability to degradation. Here, the soil Atterberg limits within different weathering profiles and their relationships with soil physicochemical properties were investigated by characterizing four collapsing gullies in four counties in the hilly granitic region of southern China. The results showed that with the fall of weathering degree, there was a sharp decrease in plastic limit, liquid limit, plasticity index, soil organic matter, cation exchange capacity and free iron oxide. Additionally, there was a gradual increase in liquidity index, a sharp increase in particle density and bulk density followed by a slight decline, a decrease in the finer soil particles, a noticeable decline in the clay contents, and a considerable increase in the gravel and sand contents. The plastic limit varied from 19.43 to $35.93 \%$ in TC, 19.51 to $33.82 \%$ in GX, 19.32 to $35.58 \%$ in $\mathrm{AX}$ and 18.91 to $36.56 \%$ in $\mathrm{WH}$, while the liquid limit varied from 30.91 to $62.68 \%$ in TC, 30.89 to $57.70 \%$ in GX, 32.48 to $65.71 \%$ in AX and 30.77 to $62.70 \%$ in WH, respectively. The soil Atterberg limits in the sandy soil layers and detritus layers were lower than those in the surface layers and red soil layers, which results in higher vulnerability of the sandy soil layers and detritus layers to erosion and finally the formation of the collapsing gully. The regression analyses showed that soil Atterberg limits had significant and positive correlation with SOM, clay
\end{abstract}

content, cationic exchange capacity and $\mathrm{Fe}_{\mathrm{d}}$, significant and negative correlation with sand content and no obvious correlation with other properties. The results of this study revealed that soil Atterberg limits are an informative indicator to reflect the weathering degree of different weathering profiles of the collapsing gullies in the hilly granitic region.

\section{Introduction}

In the early 20th century, Atterberg proposed the limits of consistency for agricultural purposes to get a clear concept of the range of water contents of a soil in the plastic state (Atterberg, 1911). These limits of consistency, namely plastic limit and liquid limit, are well known as soil Atterberg limits. Plastic limit is the boundary between semi-solid and plastic state, and liquid limit separates plastic state from liquid state (Campbell, 2001). The methods developed by Casagrande $(1932,1958)$ to determine the liquid and plastic limits are considered as standard international tests. The width of the plastic state (liquid limit minus plastic limit), the plasticity index, is very useful for characterization, classification and prediction of the engineering behavior of fine soils. Moreover, several researchers have identified the relationship between in situ water content and Atterberg limits, the liquidity index, which is an indicator of soil hardness under natural conditions (Shahminan et al.,2014; Rashid et al., 2014). Atterberg limits were used in early studies on the tillage of soils, with the plastic limit recommended as the highest possible soil water content for cultivation (Baver, 1930; 


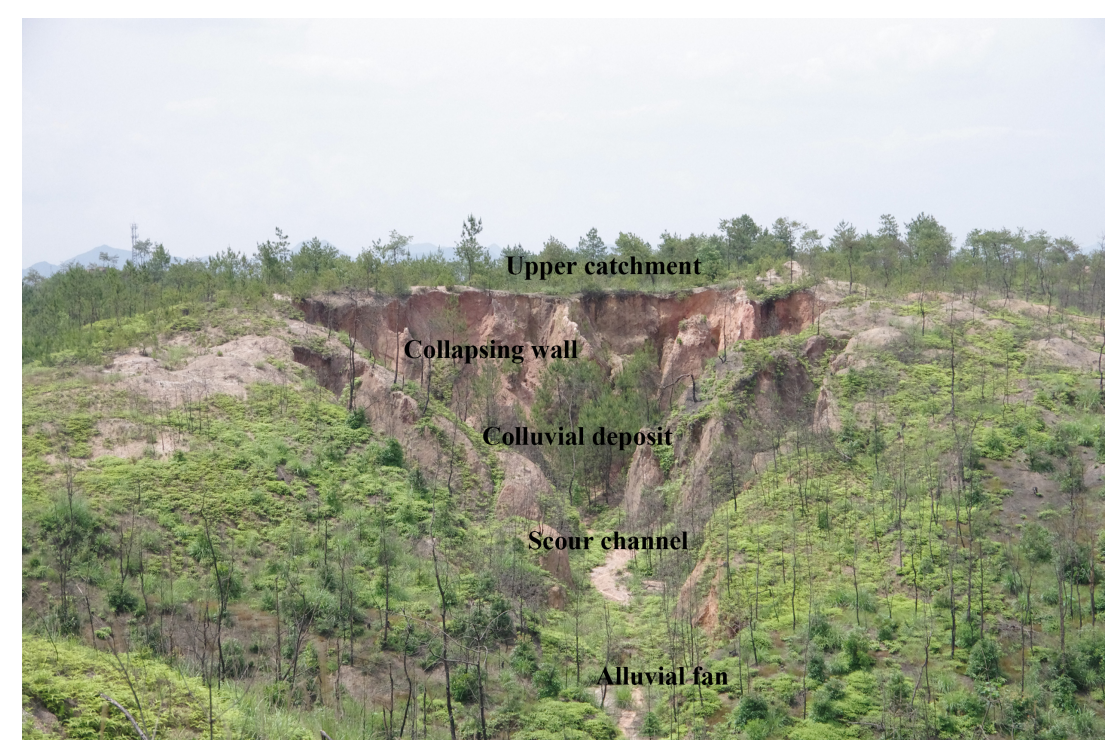

Figure 1. A typical collapsing gully in the hilly granitic region, Gan County, Jiangxi Province (photo: Yusong Deng).

Jong et al., 1990). Later on, Atterberg limits were mainly used in the classification of soils for engineering purposes. They also provide information for interpreting several soil mechanical and physical properties such as shear strength, bearing capacity, compressibility and shrinkage-swelling potential (Archer, 1975; Wroth and Wood, 1978; Cathy et al., 2008; McBride, 2008). Meanwhile, Atterberg limits are also essential for infrastructure design (e.g., construction of buildings and roads; Zolfaghari et al., 2015). These studies clearly show that there is a close relationship between Atterberg limits and certain properties of soils. More recently, Atterberg limits have been proposed as indicators for soil vulnerability to degradation processes of both natural and anthropogenic origin (Stanchi et al., 2015). Yalcin (2007) emphasized that, when subjected to water saturation, soils with limited cohesion are susceptible to erosion during heavy rainfall. Curtaz et al. (2014), Vacchiano et al. (2014) and Stanchi et al. (2012) have examined plastic limit and liquid limit in common soil types and proposed them as indicators to assess the soil vulnerability to erosion.

Soil degradation by processes such as soil erosion, shallow landslides and debris flows is a significant problem in mountainous areas, and is a crucial issue for natural hazard assessment in these areas (Jordán et al., 2014; Moreno-Ramón et al., 2014; Peng et al., 2015; Stanchi et al., 2015; MuñozRojas et al., 2016a). A collapsing gully is a serious type of soil erosion widely distributed in the hilly granitic region of southern China, which is formed in the hill slopes covered by thick granite weathering mantle (Xu, 1996). The concept of a collapsing gully was first proposed by Zeng in 1960, which is a composite erosion formed by hydraulic scour and gravitational collapse (Zeng, 1960; Jiang et al., 2014; Xia et al., 2015; Deng et al., 2016b; Xia et al., 2016). These gul- lies develop quickly and erupt suddenly, with an annual average erosion of over $50 \mathrm{kt} \mathrm{km}^{-2} \mathrm{yr}^{-1}$ in these areas, more than 50-fold faster than the erosion on gentler slopes or on slopes with high vegetation cover (Zhong et al., 2013). The flooding, debris flows, and other disasters resulting from collapsing gullies can jeopardize sustainable development in the related regions. From 1950 to 2005, gully erosion affected $1220 \mathrm{~km}^{2}$ in the granitic red clay soil region, leading to the loss of more than $60 \mathrm{Mt}$ of soil (Zhang, 2010). It is worth mentioning that the collapsing gullies in turn caused the loss of 360000 ha of farmland, 521000 houses, $36000 \mathrm{~km}$ of road, 10000 bridges, 9000 reservoirs, and 73000 ponds, as well as an economic loss of USD 3.28 billion that affected 9.17 million residents (Jiang et al., 2014; Liang et al., 2009). According to a 2005 survey by the Monitoring Center of Soil and Water Conservation of China, collapsing gullies are widely distributed in the granitic red clay soil regions of southern China, which consist of Guangdong, Jiangxi, Hubei, Hunan, Fujian, Anhui, and Guangxi provinces, with the number of collapsing gullies up to 239100 (Feng et al., 2009). A collapsing gully consists of five parts: (1) upper catchment, where a large amount of water is accumulated; (2) collapsing wall, where mass soil wasting, water erosion and gravity erosion are quite serious; (3) colluvial deposit, where residual material is deposited; (4) scour channel, where the sediment accumulation and transport is usually significantly deep and narrow; and (5) alluvial fan, the zone below the gully mouth where sediments transported by the collapse are deposited (Xu, 1996; Sheng and Liao, 1997; Xia et al., 2015; Deng et al., 2017; Fig. 1).

In a collapsing gully system, slumps and massive collapses of the collapsing wall are one of the main influential factors responsible for the collapsing gully enlargement and devel- 
opment (Xia et al., 2015). Researchers have paid close attention to the damage of collapsing gully, and found that there is a close relationship between the stability of the collapsing wall, the amount of erosion and the development speed (Xu, 1996; Sheng and Liao, 1997; Luk et al., 1997a, b; Lan et al., 2003). Qiu (1994) maintained that the mechanical composition of soil and the change in its action with water have an important influence on the development of collapsing gully. $\mathrm{Li}$ (1992) stated that there is an important relationship between the soil water content and critical height of collapsing wall, with the height being $8-9 \mathrm{~m}$ at a low water content and only 2-3 $\mathrm{m}$ in the saturated state. Zhang et al. (2013) pointed out that granite soil (an Ultisol in the south of China) is easy to disintegrate with increasing water content, and the process is irreversible. Zhang et al. (2012) proposed that the cohesion and internal friction angle of the soil showed a nonlinear attenuation trend with the increase in water content, and the shear strength index showed a peak value when the soil water content was about $13 \%$. Liu and Zhang (2015) and Deng et al. (2015) reported that the water content of the collapsing wall varied in different soil layers. Deng et al. (2016a) proposed that the soil water characteristic curve of the layers of granite is different, and the subsoil layers have greater dewatering ability than the topsoil layers. From these studies, we can find the soil water content is a common influencing factor, and the stability of the collapsing wall will vary with it. Wang et al. (2000) believe that the mechanical properties of soil will change significantly when the rain is in full contact with the soil. Similar conclusions were reported by Luk et al. (1997a), who revealed that the main cause for collapse occurrence is the short-term rainfall intensity. The soil Atterberg limits refer to the highest and lowest water content in the plastic state, which are of important significance in predicting the influence of surface runoff and rainfall on the collapsing gully. Several studies found that the soil Atterberg limits are in general influenced by many soil properties, especially by organic matter and clay content (Hemmat et al., 2010; Stanchi et al., 2015). However, few studies have been performed on the relationship between Atterberg limits and soil physicochemical properties and the occurrence of collapsing gully in the hilly granitic region of southern China.

The objectives of this study are (1) to evaluate the similarities and differences in soil Atterberg limits and soil physicochemical properties of different weathering profiles in the four collapsing gullies, (2) to investigate the relationship between soil Atterberg limits and soil physicochemical properties by analyzing the status and variation in soil Atterberg limits and (3) to explore the possibility of using soil Atterberg limits as an integrated index for quantifying collapsing gully and soil weathering degree of different weathering profiles in the hilly granitic region.

\section{Materials and methods}

\subsection{Study area}

The sampling plots $\left(22^{\circ} 58-29^{\circ} 24^{\prime} \mathrm{N}, 110^{\circ} 51-118^{\circ} 17^{\prime}\right)$ are located in the hilly granitic region of southern China, including Tongcheng County (TC) in Hubei Province, Gan County (GX) in Jiangxi Province, Anxi County (AX) in Fujian Province and Wuhua County (WH) in Guangdong Province, which are the most serious collapsing gully centers in southern China and thus were selected as the study sites. These study areas are in a temperate monsoonal continental climate zone, with an average temperature of $15-22^{\circ}$ and an average annual precipitation of about $1500 \mathrm{~mm}$ with high variability. The region is dominated by granitic red soil (an Ultisol) that developed in the Yanshan period. There were 1102, 4138, 4744 and 22117 collapsing gullies in TC, GX, $\mathrm{AX}$ and $\mathrm{WH}$, respectively. The control soil samples were collected from Xianning, Hubei.

\subsection{Soil sampling}

According to previous studies and the soil color and soil structural characteristics, the weathering profiles of the collapsing gullies of the study area in the hilly granitic region can be subdivided into four soil layers: surface layer, red soil layer, sandy soil layer and detritus layer (Luk et al., 1997a; Zhang et al., 2012; Xia et al., 2015).

The soil samples were collected in surface layer, red soil layer, sandy soil layer and detritus layer. According to the height of the collapsing gully wall, we collected $6,8,8$ and 8 soil samples in four weathered layers, respectively, with a total of 30 sampling sites. The detritus layer of the collapsing gully in Tongcheng County was not exposed, so the soil samples were not collected. The information of soil sample sites and soil sampling depth is presented in Tables 1 and 2. The soil samples of control sites were collected from four soil layers (A, B, C1, C2) in Xianning.

When collecting the samples of each soil layer, about 1$2 \mathrm{~kg}$ soil sample was obtained by means of quartering and transported to the laboratory for measurement of soil Atterberg limits (including plastic limit and liquid limit) and soil physicochemical properties (including soil particle density, organic matter, cation exchange capacity and free iron oxide). At each layer, six soil samples were obtained by using a cutting ring to determine soil bulk density and calculate the total porosity.

\subsection{Soil analysis}

The soil samples were air-dried and then sieved at the fraction $<0.452 \mathrm{~mm}$ for Atterberg limits determination, and at $<2 \mathrm{~mm}$ for measurement of soil physical and chemical properties including particle density, particle-size distribution and chemical analyses. Soil Atterberg limits (liquid limit and plastic limit) were determined using the air-dried soil for 
Table 1. Description of soil sampling sites (Xia et al., 2015).

\begin{tabular}{|c|c|c|c|c|c|c|c|}
\hline Location & $\begin{array}{l}\text { Collapsing } \\
\text { gully code }\end{array}$ & $\begin{array}{l}\text { Longitude } \\
\text { and latitude }\end{array}$ & $\begin{array}{r}\text { Altitude } \\
(\mathrm{m})\end{array}$ & $\begin{array}{r}\text { Height of } \\
\text { collapsing } \\
\text { gully wall }(\mathrm{m})\end{array}$ & $\begin{array}{r}\text { Coverage of } \\
\text { tree layer } \\
(\%)\end{array}$ & $\begin{array}{r}\text { Coverage of } \\
\text { surface } \\
\text { layer }(\%)\end{array}$ & $\begin{array}{l}\text { Vegetation } \\
\text { community }\end{array}$ \\
\hline $\begin{array}{l}\text { Tongcheng } \\
\text { County }\end{array}$ & $\mathrm{TC}$ & $\begin{array}{l}29^{\circ} 12^{\prime} 39^{\prime \prime} \mathrm{N} \\
113^{\circ} 46^{\prime} 26^{\prime \prime} \mathrm{E}\end{array}$ & 142 & 9 & 45 & 64 & $\begin{array}{l}\text { Pinus massoniana }+ \text { Cunninghamia lanceolata }+ \\
\text { Liquidambar formosana }+ \text { Phyllostachys heterocycla }- \\
\text { Rosa laevigata }+ \text { Smilax china }+ \text { Gardenia jasminoides } \\
+ \text { Vaccinium carlesii }+ \text { Lespedeza bicolor }- \\
\text { Dicranopteris linearis }+ \text { Miscanthus floridulus }\end{array}$ \\
\hline $\begin{array}{l}\text { Gan } \\
\text { County }\end{array}$ & GX & $\begin{array}{l}26^{\circ} 11^{\prime} 22.2^{\prime \prime} \mathrm{N} \\
115^{\circ} 10^{\prime} 39.4^{\prime \prime} \mathrm{E}\end{array}$ & 175 & 15 & 35 & 38 & $\begin{array}{l}\text { P. massoniana }+ \text { L. formosana }+ \text { Schima superba- } \\
\text { L. bicolor }-D . \text { linearis }\end{array}$ \\
\hline $\begin{array}{l}\text { Anxi } \\
\text { County }\end{array}$ & $\mathrm{AX}$ & $\begin{array}{l}24^{\circ} 57^{\prime} 14.3^{\prime \prime} \mathrm{N} \\
118^{\circ} 3^{\prime} 35.1^{\prime \prime} \mathrm{E}\end{array}$ & 172 & 20 & 30 & 43 & $\begin{array}{l}\text { P. massoniana }+ \text { Eucalyptus robusta }+ \text { Acacia confusa- } \\
\text { Rhus chinensis }+ \text { Rhodomyrtus tomentosa }+ \\
\text { Loropetalum chinense }-D \text {. linearis }+M \text {. floridulus }\end{array}$ \\
\hline $\begin{array}{l}\text { Wuhua } \\
\text { County }\end{array}$ & WH & $\begin{array}{l}24^{\circ} 06^{\prime} 10.4^{\prime \prime} \mathrm{N} \\
115^{\circ} 34^{\prime} 57.1^{\prime \prime} \mathrm{E}\end{array}$ & 157 & 35 & 28 & 35 & $\begin{array}{l}\text { P. massoniana }-R \text {. tomentosa }+ \\
\text { Baeckea frutescens }-D \text {. linearis }\end{array}$ \\
\hline
\end{tabular}

Table 2. Description of weathering profile, soil sampling depth and soil properties of different weathering profiles of the four collapsing gullies.

\begin{tabular}{|c|c|c|c|c|c|c|c|c|}
\hline Soil layer code & Weathering profile & $D(\mathrm{~m})$ & $\mathrm{PD}\left(\mathrm{g} \mathrm{cm}^{-3}\right)$ & $\mathrm{BD}\left(\mathrm{g} \mathrm{cm}^{-3}\right)$ & $\mathrm{TP}(\%)$ & $\mathrm{SOM}\left(\mathrm{g} \mathrm{kg}^{-1}\right)$ & $\mathrm{CEC}\left(\mathrm{cmol} \mathrm{kg}^{-1}\right)$ & $\mathrm{Fe}_{\mathrm{d}}\left(\mathrm{g} \mathrm{kg}^{-1}\right)$ \\
\hline TC1 & Surface layer & 0.3 & 2.58 & $1.29 \pm 0.05 \mathrm{~d}$ & $49.03 \pm 2.37 \mathrm{a}$ & $23.37 \pm 0.55 \mathrm{a}$ & $16.39 \pm 0.90 \mathrm{a}$ & $21.38 \pm 0.46 b c$ \\
\hline $\mathrm{TC} 2$ & Red soil layer & 0.8 & 2.64 & $1.47 \pm 0.01 \mathrm{a}$ & $44.11 \pm 0.29 c$ & $6.81 \pm 0.17 \mathrm{~b}$ & $8.37 \pm 1.14 b$ & $27.37 \pm 0.84 \mathrm{a}$ \\
\hline TC3 & Red soil layer & 2 & 2.68 & $1.34 \pm 0.05 \mathrm{c}$ & $49.53 \pm 1.79 \mathrm{a}$ & $5.84 \pm 0.20 c$ & $7.59 \pm 0.27 b$ & $23.29 \pm 1.29 b$ \\
\hline TC4 & Red soil layer & 4 & 2.65 & $1.39 \pm 0.02 b$ & $47.26 \pm 0.85 b$ & $2.68 \pm 0.13 d$ & $3.32 \pm 0.44 \mathrm{c}$ & $19.42 \pm 1.72 c$ \\
\hline TC5 & Sandy soil layer & 7 & 2.62 & $1.33 \pm 0.02 \mathrm{c}$ & $49.72 \pm 0.83 a$ & $1.20 \pm 0.11 \mathrm{e}$ & $4.07 \pm 0.61 \mathrm{c}$ & $13.84 \pm 0.93 \mathrm{~d}$ \\
\hline TC6 & Sandy soil layer & 9 & 2.65 & $1.35 \pm 0.01 \mathrm{c}$ & $48.63 \pm 0.35 \mathrm{ab}$ & $1.02 \pm 0.06 \mathrm{e}$ & $3.92 \pm 0.34 \mathrm{c}$ & $11.89 \pm 1.00 \mathrm{e}$ \\
\hline GX1 & Surface layer & 0.3 & 2.57 & $1.27 \pm 0.05 \mathrm{c}$ & $50.94 \pm 2.34 \mathrm{a}$ & $7.93 \pm 0.11 \mathrm{a}$ & $10.28 \pm 0.17 \mathrm{a}$ & $25.31 \pm 1.45 \mathrm{a}$ \\
\hline GX2 & Red soil layer & 0.8 & 2.67 & $1.40 \pm 0.03 \mathrm{ab}$ & $47.65 \pm 1.50 b$ & $1.35 \pm 0.08 b$ & $8.27 \pm 0.44 b c$ & $26.59 \pm 2.90 \mathrm{a}$ \\
\hline GX3 & Red soil layer & 1.8 & 2.64 & $1.40 \pm 0.02 \mathrm{ab}$ & $46.79 \pm 0.87 b c$ & $1.07 \pm 0.12 \mathrm{c}$ & $7.91 \pm 0.60 \mathrm{c}$ & $22.72 \pm 0.57 b c$ \\
\hline GX4 & Red soil layer & 4 & 2.63 & $1.42 \pm 0.02 \mathrm{a}$ & $46.02 \pm 0.95 \mathrm{c}$ & $0.86 \pm 0.07 \mathrm{~d}$ & $8.90 \pm 0.69 b$ & $23.96 \pm 1.11 b$ \\
\hline GX5 & Sandy soil layer & 7.5 & 2.62 & $1.41 \pm 0.02 \mathrm{ab}$ & $46.13 \pm 1.06 \mathrm{c}$ & $0.42 \pm 0.06 \mathrm{f}$ & $5.41 \pm 0.86 \mathrm{~d}$ & $18.36 \pm 0.77 \mathrm{c}$ \\
\hline GX6 & Sandy soil layer & 9 & 2.69 & $1.37 \pm 0.04 b c$ & $49.20 \pm 1.59 \mathrm{ab}$ & $0.72 \pm 0.09 \mathrm{e}$ & $5.98 \pm 0.52 \mathrm{~d}$ & $13.30 \pm 0.43 \mathrm{~d}$ \\
\hline GX7 & Detritus layer & 11 & 2.64 & $1.33 \pm 0.06 \mathrm{c}$ & $48.32 \pm 1.27 b$ & $0.40 \pm 0.06 \mathrm{f}$ & $2.09 \pm 0.19 \mathrm{e}$ & $9.90 \pm 0.78 \mathrm{e}$ \\
\hline GX8 & Detritus layer & 13.5 & 2.59 & $1.38 \pm 0.04 \mathrm{ab}$ & $46.65 \pm 1.96 b c$ & $0.71 \pm 0.11 \mathrm{e}$ & $3.43 \pm 0.36 \mathrm{e}$ & $9.41 \pm 0.63 \mathrm{e}$ \\
\hline AX1 & Surface layer & 0.3 & 2.54 & $1.31 \pm 0.06 \mathrm{c}$ & $44.40 \pm 2.78 \mathrm{~d}$ & $44.06 \pm 0.04 \mathrm{a}$ & $22.18 \pm 0.21 \mathrm{a}$ & $31.03 \pm 1.80 \mathrm{a}$ \\
\hline $\mathrm{AX} 2$ & Red soil layer & 0.8 & 2.63 & $1.39 \pm 0.06 \mathrm{ab}$ & $54.24 \pm 2.89 \mathrm{a}$ & $11.23 \pm 0.61 b$ & $14.63 \pm 1.30 \mathrm{~b}$ & $27.53 \pm 0.56 b$ \\
\hline $\mathrm{AX} 3$ & Red soil layer & 2 & 2.66 & $1.43 \pm 0.03 a$ & $52.38 \pm 1.73 \mathrm{ab}$ & $6.33 \pm 0.11 \mathrm{c}$ & $9.20 \pm 0.58 \mathrm{c}$ & $26.35 \pm 0.74 b$ \\
\hline $\mathrm{AX} 4$ & Red soil layer & 4 & 2.60 & $1.41 \pm 0.01 \mathrm{a}$ & $50.81 \pm 0.45 b$ & $2.41 \pm 0.11 \mathrm{~d}$ & $6.37 \pm 0.61 d$ & $24.38 \pm 1.11 \mathrm{c}$ \\
\hline AX5 & Sandy soil layer & 8 & 2.65 & $1.37 \pm 0.03 b$ & $48.39 \pm 1.31 b c$ & $0.82 \pm 0.03 \mathrm{f}$ & $4.82 \pm 0.18 \mathrm{e}$ & $11.87 \pm 1.04 \mathrm{~d}$ \\
\hline AX6 & Sandy soil layer & 10 & 2.54 & $1.35 \pm 0.02 b c$ & $47.01 \pm 0.88 \mathrm{c}$ & $1.31 \pm 0.09 \mathrm{e}$ & $5.02 \pm 0.27 \mathrm{de}$ & $10.55 \pm 1.23 \mathrm{~d}$ \\
\hline AX7 & Detritus layer & 12 & 2.62 & $1.32 \pm 0.02 \mathrm{c}$ & $49.50 \pm 0.82 b c$ & $0.81 \pm 0.07 f$ & $2.36 \pm 0.32 \mathrm{f}$ & $7.34 \pm 0.56 \mathrm{e}$ \\
\hline AX8 & Detritus layer & 15 & 2.53 & $1.31 \pm 0.02 \mathrm{c}$ & $48.12 \pm 1.33 \mathrm{bc}$ & $0.67 \pm 0.09 f$ & $3.80 \pm 0.71 \mathrm{ef}$ & $7.30 \pm 0.80 \mathrm{e}$ \\
\hline WH1 & Surface layer & 0.3 & 2.52 & $1.33 \pm 0.04 \mathrm{~d}$ & $48.19 \pm 0.93 \mathrm{a}$ & $15.17 \pm 1.73 \mathrm{a}$ & $13.84 \pm 0.88 \mathrm{a}$ & $28.40 \pm 0.64 \mathrm{a}$ \\
\hline WH2 & Red soil layer & 1 & 2.69 & $1.48 \pm 0.01 \mathrm{~b}$ & $44.96 \pm 0.29 c$ & $4.65 \pm 0.29 b$ & $7.69 \pm 0.39 b$ & $24.52 \pm 0.54 b$ \\
\hline WH3 & Red soil layer & 2.5 & 2.72 & $1.47 \pm 0.03 b$ & $45.68 \pm 1.15 b c$ & $2.59 \pm 0.14 \mathrm{c}$ & $6.62 \pm 0.51 b$ & $22.94 \pm 0.91 b c$ \\
\hline WH4 & Sandy soil layer & 5 & 2.68 & $1.44 \pm 0.02 \mathrm{c}$ & $46.15 \pm 0.83 b$ & $2.82 \pm 0.03 c$ & $6.54 \pm 0.45 b$ & $16.28 \pm 1.10 \mathrm{c}$ \\
\hline WH5 & Sandy soil layer & 9 & 2.63 & $1.40 \pm 0.03 \mathrm{~cd}$ & $46.44 \pm 1.64 b$ & $1.61 \pm 0.10 \mathrm{~d}$ & $4.18 \pm 0.50 c$ & $12.41 \pm 0.27 \mathrm{~d}$ \\
\hline WH6 & Sandy soil layer & 11 & 2.62 & $1.49 \pm 0.02 b$ & $43.01 \pm 1.01 \mathrm{c}$ & $0.57 \pm 0.08 \mathrm{f}$ & $2.28 \pm 0.22 \mathrm{~d}$ & $14.23 \pm 0.78 \mathrm{~cd}$ \\
\hline WH7 & Detritus layer & 14 & 2.59 & $1.54 \pm 0.03 \mathrm{a}$ & $40.34 \pm 1.46 \mathrm{~d}$ & $0.74 \pm 0.05 \mathrm{e}$ & $3.91 \pm 0.18 \mathrm{~cd}$ & $8.86 \pm 0.40 \mathrm{e}$ \\
\hline WH8 & Detritus layer & 17 & 2.61 & $1.37 \pm 0.05 \mathrm{~d}$ & $46.41 \pm 1.59 b$ & $0.23 \pm 0.18 \mathrm{~g}$ & $1.93 \pm 0.30 \mathrm{e}$ & $8.37 \pm 0.32 \mathrm{e}$ \\
\hline
\end{tabular}

Values with different letters are significantly different at the $P<0.05$ level among the different soil layers of the same collapsing gully. SOM: soil organic matter; Fe $\mathrm{d}_{\mathrm{d}}$ free iron oxide.

each layer according to the cone penetrometer and the thread roll method (Stanchi et al., 2015), which are reported in S.I.S.S (1997) after ASTM D 4318-10e1 (2010), i.e. the plasticity index and the liquidity index are obtained by the following Eqs. $(1,2)$ :

Plasticity index = liquid limit- plastic limit,

Liquidity index $=\left(\mathrm{WC}_{\text {insitu }}-\right.$ plastic limit $) /$ (liquid limit - plastic limit),

where $\mathrm{WC}_{\text {insitu }}$ is in situ water content.

The particle density (PD) was measured by the pycnometer method, the bulk density (BD) was determined by the cutting ring method, and the total porosity (TP) was calculated as $\mathrm{TP}=1-(\mathrm{BD} / \mathrm{PD})$ (Anderson and Ingram, 1993; Cerdà and Doerr, 2010). The particle-size distribution (PSD) was determined by the sieve-and-pipette method (Gee and 

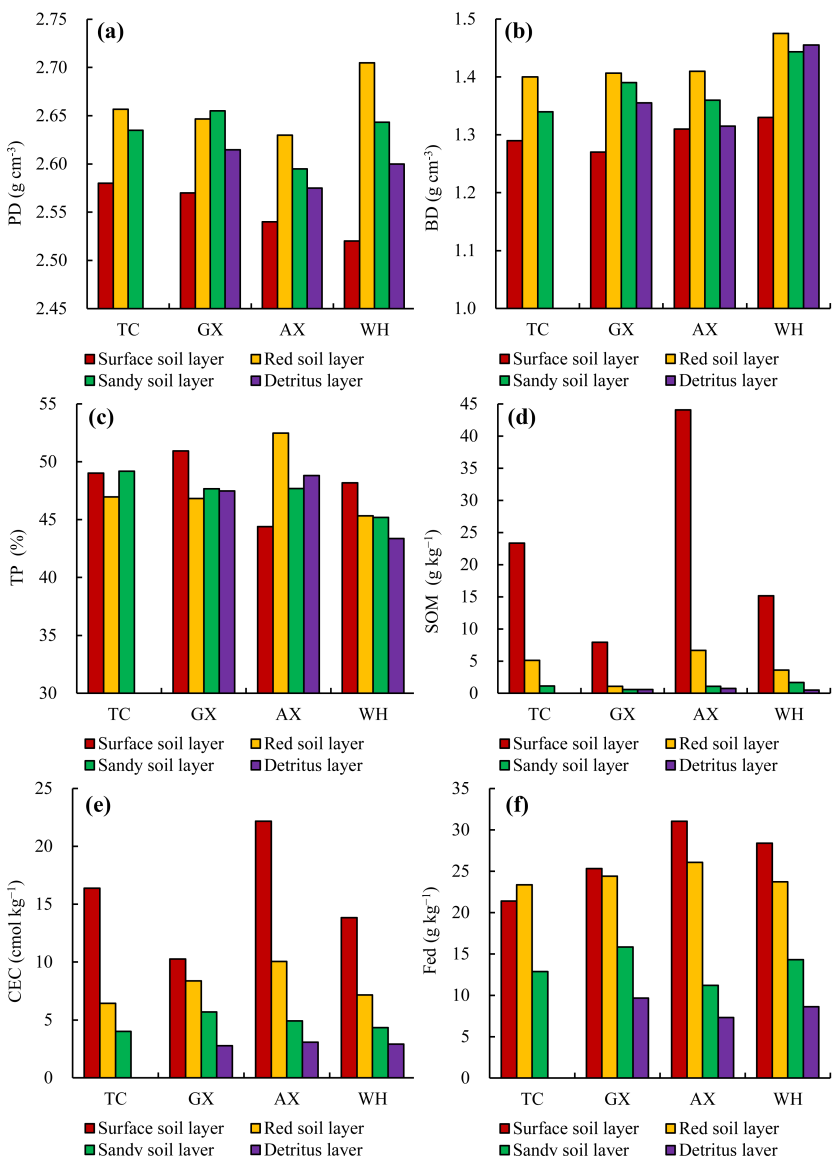

Figure 2. Averages of soil properties for different weathering profiles of the four collapsing gullies. (a) Particle density, (b) bulk density, (c) total porosity, (d) soil organic matter, (e) cation exchange capacity and (f) free iron oxide.

Bauder, 1986). Soil organic matter (SOM) was measured by the $\mathrm{K}_{2} \mathrm{Cr}_{2} \mathrm{O}_{7}-\mathrm{H}_{2} \mathrm{SO}_{4}$ oxidation method of Walkey and Black (Nelson and Sommers, 1982). Cation exchange capacity (CEC) was measured after extraction with ammonium acetate (Rhoades, 1982). Free iron oxide $\left(\mathrm{Fe}_{\mathrm{d}}\right)$ was extracted by dithionite-citrate-bicarbonate (DCB; Mehra and Jackson, 1958).

\subsection{Statistical analysis}

Statistical analyses were performed using SPSS 19.0 software (SPSS Inc., Chicago, IL, USA). A one-way analysis of variance (ANOVA) was performed to examine the effects of soil depth on soil Atterberg limits and soil physicochemical properties. The least squares difference (LSD) test (at $P<0.05)$ was used to compare means of soil variables when the results of ANOVA were significant at $P<0.05$. Regression analysis was used to analyze the relationship between soil Atterberg limits and soil physicochemical properties.

\section{Results and discussion}

\subsection{Soil physicochemical properties}

The soil physical and chemical properties for the different weathering profiles in the four collapsing gullies (TC, GX, $\mathrm{AX}$ and $\mathrm{WH}$ ) were described in terms of soil particle density (PD), soil bulk density (BD), total porosity (TP), soil organic matter (SOM), cation exchange capacity (CEC), free iron oxide $\left(\mathrm{Fe}_{\mathrm{d}}\right)$ and particle-size distribution (PSD). The values for these properties are shown in Tables 2 and 3. Average values at varying soil layers including surface soil layer, red soil layer, sandy soil layer and detritus layer are given in Figs. 2 and 3.

\subsubsection{Soil particle density (PD)}

From Table 2, it can be seen that the soil PD was the highest in TC3 $\left(2.68 \mathrm{~g} \mathrm{~cm}^{-3}\right)$, GX6 $\left(2.69 \mathrm{~g} \mathrm{~cm}^{-3}\right)$, AX3 $\left(2.66 \mathrm{~g} \mathrm{~cm}^{-3}\right)$ and WH3 $\left(2.72 \mathrm{~g} \mathrm{~cm}^{-3}\right)$ of each collapsing gully, but the lowest in TC1 $\left(2.58 \mathrm{~g} \mathrm{~cm}^{-3}\right), \mathrm{GX} 1$ $\left(2.57 \mathrm{~g} \mathrm{~cm}^{-3}\right)$, AX8 $\left(2.53 \mathrm{~g} \mathrm{~cm}^{-3}\right)$ and WH1 $\left(2.52 \mathrm{~g} \mathrm{~cm}^{-3}\right)$. Significant differences $(P<0.01)$ were observed in the average PD values of the different soil layers in TC, GX, AX and WH (Fig. 2a). The PD was the lowest in the surface soil layer, followed by the detritus layer. In addition, the highest PD was observed in the red soil layer of TC, AX and WH and the sandy soil layer of GX. Furthermore, as shown in Table 2, most of the soil PD values in all the four soil layers were less than $2.65 \mathrm{~g} \mathrm{~cm}^{-3}$, which are often used to calculate the value of soil BD (Lee et al., 2009; Sharma and Bora, 2015). The lower PD value may be due to the loose structure of granite soil (Luk et al., 1997a).

\subsubsection{Bulk density (BD)}

From Table 2, it can also be seen that soil BD values were the lowest in the surface layer of all the collapsing gullies (1.29, $1.27,1.21$ and $1.33 \mathrm{~g} \mathrm{~cm}^{-3}$ for TC, GX, AX and $\mathrm{WH}$, respectively). However, relatively higher BD values were observed in the red soil layer $\left(1.47,1.42,1.43\right.$ and $1.48 \mathrm{~g} \mathrm{~cm}^{-3}$ for $\mathrm{TC}, \mathrm{GX}, \mathrm{AX}$ and $\mathrm{WH}$, respectively), followed by the sandy layer. The average soil BD values had significant difference $(p<0.01)$ in the different soil layers of TC, GX, AX and WH except in the surface layer of WH (Fig. 2b). Meanwhile, the bulk density first increased sharply $(p<0.01)$ and thus declined slightly from the surface layer to the sandy soil layer of TC and to the detritus layer of GX, AX and WH (Table 2), which are similar to the report by Perrin et al. (2014). The soil $\mathrm{BD}$ values of the surface layer were lower than those of the other layers, probably due to the higher content of SOM, more plant root distribution, and better soil structure and texture (Huang et al., 2014). The bulk density of the red soil layers was higher probably because the natural compact structure was maintained (Masto et al., 2015). The lower soil BD 
Table 3. Percentages of different particle-size distributions of different weathering profiles of the four collapsing gullies.

\begin{tabular}{|c|c|c|c|c|c|c|c|c|c|c|}
\hline \multirow[b]{3}{*}{ Soil layer code } & \multicolumn{10}{|c|}{ Mass percentages of soil particle-size distribution (mm) } \\
\hline & \multirow{2}{*}{$\begin{array}{c}\text { Gravel } \\
2.0-1.0\end{array}$} & \multicolumn{2}{|c|}{ Coarse sand } & \multicolumn{2}{|c|}{ Fine sand } & \multicolumn{4}{|c|}{ Silt } & \multirow{2}{*}{$\begin{array}{r}\text { Clay } \\
<0.002\end{array}$} \\
\hline & & $1.0-0.5$ & $0.5-0.25$ & $0.25-0.15$ & $0.15-0.05$ & $0.05-0.02$ & $0.02-0.01$ & $0.01-0.005$ & $0.005-0.002$ & \\
\hline $\mathrm{TC} 1$ & $9.24 \pm 1.61 \mathrm{~b}$ & $7.13 \pm 0.10 \mathrm{~d}$ & $7.09 \pm 1.35 \mathrm{~b}$ & $3.97 \pm 0.64 d$ & $9.86 \pm 0.93 c$ & $6.55 \pm 1.67 \mathrm{~d}$ & $12.07 \pm 0.59 \mathrm{a}$ & $5.16 \pm 0.58 \mathrm{c}$ & $6.11 \pm 0.81 b$ & $32.81 \pm 1.46 \mathrm{~b}$ \\
\hline $\mathrm{TC} 2$ & $7.87 \pm 0.65 b$ & $6.55 \pm 0.12 \mathrm{e}$ & $6.12 \pm 0.54 \mathrm{c}$ & $6.10 \pm 0.07 \mathrm{c}$ & $6.24 \pm 0.93 \mathrm{~d}$ & $16.67 \pm 1.04 \mathrm{a}$ & $9.81 \pm 0.50 \mathrm{~b}$ & $6.18 \pm 1.07 \mathrm{~b}$ & $5.54 \pm 0.92 \mathrm{c}$ & $28.91 \pm 0.62 \mathrm{c}$ \\
\hline TC3 & $4.51 \pm 0.36 \mathrm{c}$ & $4.91 \pm 0.24 \mathrm{f}$ & $5.27 \pm 0.11 \mathrm{~d}$ & $6.72 \pm 0.85 b c$ & $10.55 \pm 1.14 \mathrm{c}$ & $6.34 \pm 1.22 \mathrm{~d}$ & $9.74 \pm 1.16 \mathrm{~b}$ & $3.66 \pm 0.84 \mathrm{~d}$ & $7.26 \pm 0.21 \mathrm{a}$ & $41.03 \pm 0.72 \mathrm{a}$ \\
\hline TC4 & $3.05 \pm 0.55 \mathrm{~d}$ & $7.95 \pm 0.54 c$ & $9.78 \pm 1.08 \mathrm{a}$ & $9.19 \pm 1.32 \mathrm{a}$ & $17.66 \pm 1.57 \mathrm{a}$ & $6.25 \pm 0.60 \mathrm{~d}$ & $10.97 \pm 0.96 \mathrm{a}$ & $3.27 \pm 0.63 \mathrm{~d}$ & $5.69 \pm 0.55 c$ & $26.19 \pm 1.86 \mathrm{~d}$ \\
\hline TC5 & $5.34 \pm 0.71 \mathrm{c}$ & $11.14 \pm 0.38 \mathrm{~b}$ & $11.75 \pm 0.78 \mathrm{a}$ & $10.21 \pm 1.05 \mathrm{a}$ & $13.68 \pm 1.45 \mathrm{~b}$ & $14.01 \pm 1.16 \mathrm{~b}$ & $9.44 \pm 0.17 \mathrm{~b}$ & $7.54 \pm 0.25 \mathrm{a}$ & $6.64 \pm 0.79 b$ & $10.24 \pm 0.18 \mathrm{e}$ \\
\hline TC6 & $19.84 \pm 2.28 \mathrm{a}$ & $14.63 \pm 0.58 \mathrm{a}$ & $11.95 \pm 1.23 \mathrm{a}$ & $7.58 \pm 0.37 \mathrm{~b}$ & $16.46 \pm 1.04 \mathrm{a}$ & $8.28 \pm 0.91 \mathrm{c}$ & $8.48 \pm 0.98 \mathrm{c}$ & $5.20 \pm 0.33 c$ & $3.71 \pm 0.13 \mathrm{~d}$ & $3.87 \pm 0.48 f$ \\
\hline GX1 & $8.99 \pm 0.37 \mathrm{~d}$ & $4.78 \pm 0.10 \mathrm{~d}$ & $4.43 \pm 0.29 \mathrm{e}$ & $3.94 \pm 0.18 \mathrm{e}$ & $12.77 \pm 0.34 \mathrm{f}$ & $2.92 \pm 0.25 \mathrm{e}$ & $5.49 \pm 0.78 \mathrm{~d}$ & $6.09 \pm 1.03 \mathrm{e}$ & $13.92 \pm 1.65 \mathrm{a}$ & $36.65 \pm 1.85 \mathrm{a}$ \\
\hline GX2 & $8.12 \pm 0.31 \mathrm{e}$ & $4.66 \pm 0.19 \mathrm{~d}$ & $4.41 \pm 0.05 \mathrm{e}$ & $4.17 \pm 0.22 \mathrm{e}$ & $13.62 \pm 0.31 \mathrm{de}$ & $4.14 \pm 0.66 \mathrm{~d}$ & $7.92 \pm 1.27 \mathrm{bc}$ & $7.00 \pm 1.10 \mathrm{~d}$ & $12.85 \pm 1.62 \mathrm{a}$ & $33.10 \pm 1.80 \mathrm{~b}$ \\
\hline GX3 & $9.89 \pm 0.50 \mathrm{c}$ & $5.65 \pm 0.21 \mathrm{c}$ & $6.19 \pm 0.25 \mathrm{~d}$ & $5.32 \pm 0.41 \mathrm{~d}$ & $16.40 \pm 1.03 \mathrm{c}$ & $9.24 \pm 0.33 \mathrm{c}$ & $7.19 \pm 1.74 \mathrm{c}$ & $8.50 \pm 0.65 \mathrm{a}$ & $10.37 \pm 0.88 b$ & $21.25 \pm 1.14 \mathrm{c}$ \\
\hline GX4 & $8.85 \pm 0.71 \mathrm{~d}$ & $5.68 \pm 0.30 \mathrm{c}$ & $7.93 \pm 0.31 \mathrm{~b}$ & $8.68 \pm 0.53 b$ & $18.72 \pm 1.27 \mathrm{~b}$ & $8.80 \pm 0.45 c$ & $8.09 \pm 0.21 b$ & $7.65 \pm 0.48 c$ & $9.81 \pm 0.41 \mathrm{bc}$ & $15.78 \pm 0.39 \mathrm{~d}$ \\
\hline GX5 & $9.71 \pm 1.30 \mathrm{~cd}$ & $5.03 \pm 0.25 \mathrm{~d}$ & $4.17 \pm 0.39 \mathrm{e}$ & $4.91 \pm 0.42 \mathrm{~d}$ & $27.91 \pm 0.96 \mathrm{a}$ & $11.14 \pm 0.54 b$ & $8.49 \pm 1.4 b$ & $6.68 \pm 1.43 \mathrm{~d}$ & $7.69 \pm 1.25 \mathrm{~d}$ & $14.29 \pm 0.55 \mathrm{~d}$ \\
\hline GX6 & $12.13 \pm 0.73 b$ & $7.90 \pm 0.19 b$ & $7.30 \pm 0.19 \mathrm{c}$ & $8.69 \pm 0.40 \mathrm{~b}$ & $16.40 \pm 0.34 c$ & $12.44 \pm 0.52 \mathrm{a}$ & $8.62 \pm 0.59 b$ & $8.24 \pm 0.53 \mathrm{a}$ & $9.37 \pm 0.71 \mathrm{c}$ & $8.90 \pm 0.42 \mathrm{f}$ \\
\hline GX7 & $14.87 \pm 1.28 \mathrm{a}$ & $8.87 \pm 0.14 \mathrm{a}$ & $8.60 \pm 0.81 \mathrm{ab}$ & $9.84 \pm 0.99 a$ & $14.60 \pm 0.72 \mathrm{~d}$ & $10.37 \pm 1.63 b c$ & $6.03 \pm 0.82 \mathrm{~d}$ & $8.83 \pm 0.17 \mathrm{a}$ & $4.44 \pm 1.99 \mathrm{e}$ & $13.55 \pm 1.39 \mathrm{de}$ \\
\hline GX8 & $15.83 \pm 0.85 \mathrm{a}$ & $8.80 \pm 0.07 \mathrm{a}$ & $8.67 \pm 0.20 \mathrm{a}$ & $8.09 \pm 0.62 c$ & $13.15 \pm 0.99 \mathrm{ef}$ & $11.18 \pm 1.11 \mathrm{ab}$ & $9.73 \pm 1.47 \mathrm{a}$ & $7.68 \pm 0.31 \mathrm{c}$ & $5.31 \pm 1.46 \mathrm{e}$ & $11.55 \pm 1.11 \mathrm{e}$ \\
\hline $\mathrm{AX} 1$ & $19.32 \pm 0.48 c$ & $7.55 \pm 0.42 \mathrm{c}$ & $6.67 \pm 0.23 c$ & $3.86 \pm 0.18 \mathrm{~d}$ & $6.52 \pm 0.94 \mathrm{~d}$ & $5.04 \pm 0.95 \mathrm{~d}$ & $6.02 \pm 0.37 \mathrm{~d}$ & $3.63 \pm 0.47 \mathrm{e}$ & $7.93 \pm 0.24 c$ & $33.47 \pm 1.39 \mathrm{~b}$ \\
\hline $\mathrm{AX} 2$ & $6.23 \pm 0.35 \mathrm{e}$ & $5.34 \pm 0.16 \mathrm{~d}$ & $4.10 \pm 0.31 \mathrm{~d}$ & $2.90 \pm 0.23 \mathrm{ef}$ & $4.42 \pm 0.33 \mathrm{e}$ & $3.47 \pm 0.71 \mathrm{e}$ & $4.01 \pm 0.19 \mathrm{e}$ & $6.34 \pm 1.12 \mathrm{c}$ & $11.53 \pm 1.90 \mathrm{ab}$ & $51.66 \pm 1.54 \mathrm{a}$ \\
\hline $\mathrm{AX} 3$ & $6.39 \pm 0.25 \mathrm{e}$ & $5.66 \pm 0.21 \mathrm{~d}$ & $3.99 \pm 0.43 \mathrm{~d}$ & $3.21 \pm 0.13 \mathrm{e}$ & $6.42 \pm 1.02 \mathrm{~d}$ & $4.19 \pm 0.97 \mathrm{de}$ & $1.60 \pm 0.62 \mathrm{f}$ & $5.64 \pm 1.35 \mathrm{~cd}$ & $9.61 \pm 0.69 b$ & $53.27 \pm 1.47 \mathrm{a}$ \\
\hline AX4 & $8.65 \pm 0.74 d$ & $4.63 \pm 0.08 \mathrm{e}$ & $3.31 \pm 0.16 \mathrm{e}$ & $2.48 \pm 0.50 \mathrm{f}$ & $12.22 \pm 1.02 \mathrm{c}$ & $3.92 \pm 1.81 \mathrm{e}$ & $8.27 \pm 1.17 \mathrm{ab}$ & $11.65 \pm 0.56 \mathrm{a}$ & $12.91 \pm 1.91 \mathrm{a}$ & $31.96 \pm 0.55 b$ \\
\hline AX5 & $19.86 \pm 0.87 b c$ & $8.71 \pm 0.23 b$ & $6.08 \pm 0.29 \mathrm{c}$ & $5.35 \pm 0.12 \mathrm{c}$ & $14.30 \pm 1.81 \mathrm{bc}$ & $8.62 \pm 0.48 c$ & $8.02 \pm 1.53 b$ & $8.35 \pm 0.37 b$ & $4.04 \pm 1.32 \mathrm{~d}$ & $16.68 \pm 1.10 \mathrm{c}$ \\
\hline AX6 & $24.49 \pm 1.05 \mathrm{a}$ & $10.01 \pm 0.42 \mathrm{a}$ & $7.66 \pm 0.45 b$ & $6.44 \pm 1.02 \mathrm{ab}$ & $15.82 \pm 1.44 \mathrm{ab}$ & $10.71 \pm 0.50 \mathrm{~b}$ & $6.87 \pm 1.11 \mathrm{~cd}$ & $6.58 \pm 1.13 \mathrm{c}$ & $4.27 \pm 0.07 \mathrm{~d}$ & $7.14 \pm 1.33 \mathrm{~d}$ \\
\hline $\mathrm{AX7}$ & $19.15 \pm 0.35 c$ & $7.83 \pm 0.27 \mathrm{c}$ & $7.04 \pm 0.57 \mathrm{~b}$ & $5.95 \pm 0.69 \mathrm{~b}$ & $15.96 \pm 0.78 \mathrm{a}$ & $15.85 \pm 1.12 \mathrm{a}$ & $8.00 \pm 0.74 b c$ & $8.00 \pm 0.48 b$ & $3.78 \pm 0.73 \mathrm{~d}$ & $8.45 \pm 0.31 \mathrm{~d}$ \\
\hline AX8 & $21.02 \pm 1.37 \mathrm{~b}$ & $10.93 \pm 0.43 \mathrm{a}$ & $10.86 \pm 0.98 \mathrm{a}$ & $7.94 \pm 1.76 a$ & $17.48 \pm 1.97 \mathrm{a}$ & $8.73 \pm 1.08 c$ & $9.00 \pm 0.30 \mathrm{a}$ & $5.01 \pm 0.27 \mathrm{~d}$ & $1.02 \pm 0.49 \mathrm{e}$ & $8.00 \pm 1.25 \mathrm{~d}$ \\
\hline WH1 & $18.53 \pm 0.62 \mathrm{f}$ & $5.67 \pm 0.12 \mathrm{c}$ & $3.74 \pm 0.17 \mathrm{c}$ & $2.30 \pm 0.39 \mathrm{~d}$ & $10.24 \pm 1.15 \mathrm{a}$ & $9.33 \pm 1.30 \mathrm{a}$ & $5.55 \pm 0.19 \mathrm{~d}$ & $4.59 \pm 0.62 \mathrm{~d}$ & $7.42 \pm 1.85 \mathrm{~d}$ & $32.62 \pm 1.30 \mathrm{a}$ \\
\hline WH2 & $23.42 \pm 0.40 \mathrm{~d}$ & $5.78 \pm 0.09 \mathrm{c}$ & $2.93 \pm 0.21 \mathrm{de}$ & $2.29 \pm 0.05 \mathrm{~d}$ & $6.89 \pm 0.74 c$ & $7.34 \pm 0.56 \mathrm{c}$ & $8.51 \pm 1.28 \mathrm{a}$ & $3.70 \pm 0.55 \mathrm{~d}$ & $10.23 \pm 1.32 \mathrm{c}$ & $28.92 \pm 2.22 \mathrm{~b}$ \\
\hline WH3 & $25.72 \pm 1.91 \mathrm{~b}$ & $5.92 \pm 0.29 c$ & $2.76 \pm 0.08 \mathrm{e}$ & $1.97 \pm 0.05 \mathrm{~d}$ & $5.15 \pm 0.18 \mathrm{~d}$ & $5.74 \pm 0.53 \mathrm{~d}$ & $4.29 \pm 0.63 \mathrm{e}$ & $8.72 \pm 0.93 c$ & $12.91 \pm 0.15 b$ & $26.83 \pm 1.82 \mathrm{~b}$ \\
\hline WH4 & $22.26 \pm 1.33 \mathrm{de}$ & $6.39 \pm 0.21 b$ & $3.24 \pm 0.25 \mathrm{~d}$ & $2.06 \pm 0.10 \mathrm{~d}$ & $4.96 \pm 1.10 \mathrm{~d}$ & $5.45 \pm 1.25 \mathrm{~d}$ & $7.09 \pm 1.00 \mathrm{bc}$ & $9.10 \pm 0.60 c$ & $16.07 \pm 1.60 \mathrm{a}$ & $23.38 \pm 1.97 \mathrm{c}$ \\
\hline WH5 & $24.53 \pm 0.62 c$ & $8.46 \pm 0.16 \mathrm{a}$ & $4.29 \pm 0.27 b$ & $3.05 \pm 0.14 \mathrm{c}$ & $5.67 \pm 1.34 \mathrm{~d}$ & $7.02 \pm 0.76 c$ & $4.04 \pm 0.94 \mathrm{e}$ & $15.15 \pm 1.85 \mathrm{a}$ & $10.23 \pm 1.03 c$ & $17.54 \pm 1.67 \mathrm{~d}$ \\
\hline WH6 & $27.73 \pm 0.23 \mathrm{a}$ & $8.50 \pm 0.41 \mathrm{a}$ & $5.00 \pm 0.49 \mathrm{a}$ & $4.40 \pm 0.37 b$ & $3.06 \pm 0.38 \mathrm{e}$ & $10.94 \pm 1.25 \mathrm{a}$ & $6.98 \pm 1.34 \mathrm{bc}$ & $12.39 \pm 0.65 b$ & $10.06 \pm 1.73 \mathrm{c}$ & $10.93 \pm 1.38 \mathrm{e}$ \\
\hline WH7 & $25.81 \pm 0.25 b$ & $8.54 \pm 0.05 \mathrm{a}$ & $5.29 \pm 0.29 \mathrm{a}$ & $5.57 \pm 0.24 \mathrm{a}$ & $9.27 \pm 0.86 \mathrm{ab}$ & $8.36 \pm 1.80 \mathrm{ab}$ & $6.73 \pm 0.73 \mathrm{c}$ & $14.46 \pm 1.25 \mathrm{ab}$ & $5.56 \pm 0.38 \mathrm{~d}$ & $10.42 \pm 0.79 \mathrm{e}$ \\
\hline WH8 & $25.16 \pm 0.82 b$ & $8.48 \pm 0.17 \mathrm{a}$ & $5.42 \pm 0.08 \mathrm{a}$ & $5.24 \pm 0.61 \mathrm{a}$ & $8.43 \pm 0.49 \mathrm{~b}$ & $7.40 \pm 1.66 b c$ & $7.55 \pm 1.80 \mathrm{ab}$ & $15.65 \pm 1.21 \mathrm{a}$ & $10.91 \pm 0.57 \mathrm{c}$ & $5.77 \pm 0.82 \mathrm{f}$ \\
\hline
\end{tabular}

values of the sandy layer and detritus layer may be due to weak weathering and loose soil structure (Lan et al., 2013).

\subsubsection{Total porosity (TP)}

Unlike soil $\mathrm{BD}$, the soil TP was comparatively high in the surface soil layer of GX and WH, but was the highest in the red soil layer of AX (Fig. 2c). From Table 2, it can be seen that the soil TP values were lower in the red soil layer, such as TC2 $(44.11 \%)$ and GX4 (46.02\%), which may be due to the weathering process of these soil layers, feldspar and mica in mineralized granites (Deng et al., 2016b).

\subsubsection{Soil organic matter (SOM)}

Soil organic matter (SOM) plays an important role in soil nutrient availability, and its increase may decrease the potential of soil erosion (Oliveira et al., 2015). As shown in Table 2, with the increase in depth, SOM contents in the soil layers of the four collapsing gullies showed a sharply decreasing trend $(P<0.01)$. The sandy soil layers and detritus layers showed relatively lower SOM contents than those in the red soil layers and surface layers (Fig. 2d). The AX1 had the highest SOM content $\left(44.06 \mathrm{~g} \mathrm{~kg}^{-1}\right)$, followed by TC1 (23.37 $\left.\mathrm{g} \mathrm{kg}^{-1}\right)$, WH1 $\left(15.17 \mathrm{~g} \mathrm{~kg}^{-1}\right)$ and AX2 (11.23 $\mathrm{g} \mathrm{kg}^{-1}$; Table 2), which is mainly due to the decomposition of surface litter in the ground surface. However, the sandy soil layer and the detritus layer are basically in the state of incomplete weathering, and there is no accumulation of SOM (Xia et al., 2015).

\subsubsection{Cation exchange capacity (CEC)}

Cationic exchange capacity (CEC) is a measure of the soil capacity to adsorb and release cations (Jordán et al., 2009; Khaledian et al., 2016; Muñoz-Rojas et al., 2016b). Similar to the SOM trend, CEC also decreased significantly from the topsoil layers to the subsoil layers in the four collapsing gullies. As shown in Table 2, the CEC values were the highest in the surface soil layer of the four gullies $(1.29,1.27,1.21$ and $1.33 \mathrm{~g} \mathrm{~cm}^{-3}$ for TC1, GX1, AX1 and WH1, respectively). The average CEC values followed the order of surface soil layer $>$ red soil layer $>$ sandy soil layer $>$ detritus layer with significant difference $(P<0.01$; Fig. $2 \mathrm{e})$.

\subsubsection{Free iron oxide $\left(\mathrm{Fe}_{\mathrm{d}}\right)$}

$\mathrm{Fe}_{\mathrm{d}}$ is the secondary product formed by the weathering of the parent rock during soil formation. One $\mathrm{Fe}_{\mathrm{d}}$ state of the film surface is wrapped in the shape of clay minerals, and another state may be filled in the micropores of clay minerals (Cerdà et al., 2002; Lan et al., 2013). It is a unique and very important cementing material in weathered soil. As shown in Table 2, $\mathrm{Fe}_{\mathrm{d}}$ values were the lowest in the detritus layer of all the collapsing gullies $\left(11.89,9.41,7.30\right.$ and $8.37 \mathrm{~g} \mathrm{~kg}^{-1}$ for TC, GX, AX and WH, respectively). The highest $\mathrm{Fe}_{\mathrm{d}}$ values of $\mathrm{AX}$ and $\mathrm{WH}$ were observed in the surface soil layer (31.03 and $28.40 \mathrm{~g} \mathrm{~kg}^{-1}$ for $\mathrm{AX}$ and $\mathrm{WH}$ ), while those of TC and GX were observed in the red soil layer (27.37 and $26.59 \mathrm{~g} \mathrm{~kg}^{-1}$ for TC and GX). Overall, there are significant differences between surface soil layer, red soil layer, sandy 


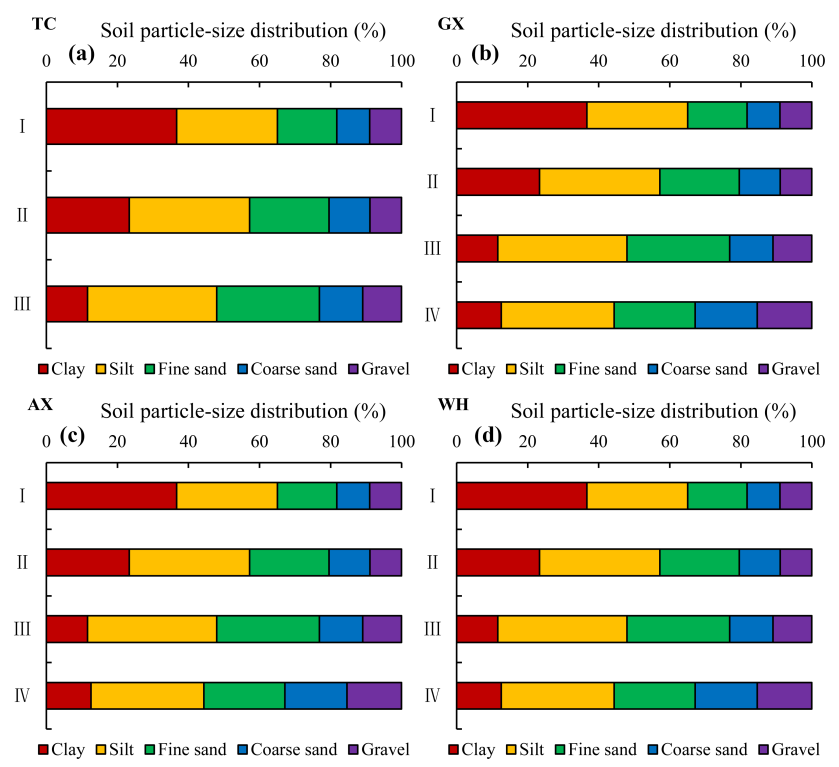

Figure 3. Averages of different particle-size distributions for different weathering profiles of the four collapsing gullies. (a) Tongcheng County, (b) Ganxian County, (c) Anxi County and (d) Wuhua County.

soil layer and detritus layer in different weathering profiles (Fig. 2f). These results show that the structural and mechanical properties are stronger in the surface soil layers and the red soil layers. However, when compared to the topsoil layers, the soil structure is loose and the cohesive strength is low in the sandy soil layer and detritus layer.

\subsubsection{Particle-size distribution (PSD)}

Soil particle-size distribution (PSD) is one of the most important physical attributes in soil systems (Hillel, 1980). PSD affects the movement and retention of water, solutes, heat, and air, and thus greatly affects soil properties (Arjmand Sajjadi et al., 2015). The highest clay contents were 41.03, 36.65, 53.27 and $32.62 \%$ in TC, GX, AX and WH, respectively, and silt varied from 25.67 to $38.21 \%$ in TC, 28.43 to $38.68 \%$ in GX, 21.06 to $36.75 \%$ in $\mathrm{AX}$ and 26.90 to $41.51 \%$ in WH. The averages of particle-size distributions for different weathering profiles of the four collapsing gullies are shown in Fig. 3. The results indicated that the finer soil particles declined and the coarse soil particles increased from the surface layer to detritus layer. The surface layer of TC, GX and WH collapsing gullies had the greatest clay content of 32.81 , 36.65 and $32.62 \%$, respectively, while the red soil layer of the AX collapsing gully showed the greatest clay content $(45.63 \%)$. This phenomenon can be attributed to the different weathering degree of granite: the grain size becomes coarser, the $\mathrm{SiO}_{2}$ content and sand content increase, and the clay content decreases from the top to the bottom (Xu, 1996; Lin et al., 2015).
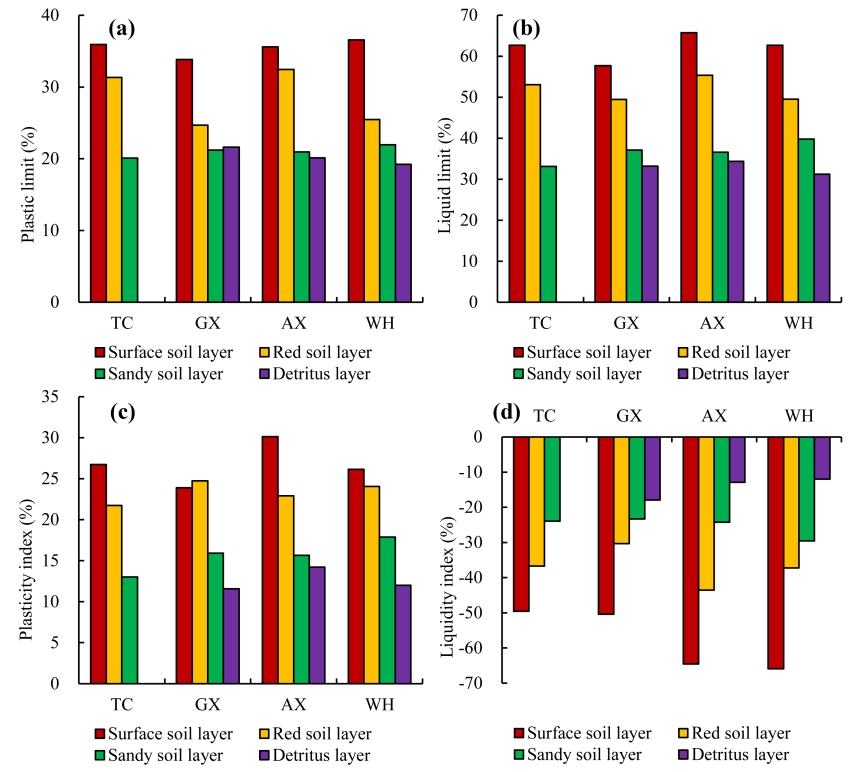

Figure 4. Averages of soil Atterberg limits for different weathering profiles of the four collapsing gullies. (a) Plastic limit, (b) liquid limit, (c) plasticity index and (d) liquidity index.

\subsection{Soil Atterberg limits characteristics of weathering profiles of the collapsing gullies}

All the measured soil plastic limit and liquid limit values varied significantly in the different soil layers. Table 4 lists the calculated values for the Atterberg limits, plasticity index and liquidity index. The average values for these properties are shown in Fig. 4 and the relationships of these values with soil depth are shown in Fig. 5.

\subsubsection{Soil plastic limit and liquid limit}

As shown in Table 4, soil plastic limit and liquid limit varied greatly from the top to the bottom of different soil layers. Specifically, the soil plastic limit ranged from 19.43 (TC6) to $35.93 \%$ (TC1) with an average of $28.34 \%$ in TC, 19.51 (GX6) to $33.82 \%$ (GX1) with an average of $24.19 \%$ in GX, 19.32 (AX7) to $36.03 \%$ (AX2) with an average of $26.87 \%$ in $\mathrm{AX}$, and 18.91 (WH8) to $36.56 \%$ (WH8) with an average of $23.98 \%$ in WH. Consistent with the variation trend of plastic limit, the soil liquid limit was found to be highest in TC1 (62.68\%), GX1 (57.70\%), AX1 (65.71\%) and WH1 $(62.70 \%)$ in each weathering profile of the four collapsing gullies, and lowest in TC6 (30.91\%), GX6 (30.89\%), AX8 $(32.48 \%)$ and $\mathrm{WH} 7(30.77 \%)$. The averages of soil plastic limit and liquid limit are shown in Table 4. The results indicated that, with declining weathering degree (from the surface layer to detritus layer), both of them decreased noticeably $(P<0.01$; Figs. 5a; 7b). The surface layer of all the four collapsing gullies had the greatest soil Atterberg limits $(35.93,33.82,35.58$ and $36.56 \%$ for the plastic limit, and 
Table 4. Soil Atterberg limits of different weathering profiles of the four collapsing gullies.

\begin{tabular}{|c|c|c|c|c|}
\hline Soil layer code & Plastic limit (\%) & Liquid limit (\%) & Plasticity index (\%) & Liquidity index (\%) \\
\hline TC1 & $35.93 \pm 0.69 a$ & $62.68 \pm 1.32 \mathrm{a}$ & $26.75 \pm 2.01 \mathrm{a}$ & $-49.55 \pm 3.74 d$ \\
\hline TC2 & $31.73 \pm 2.25 b$ & $53.09 \pm 0.20 \mathrm{bc}$ & $21.36 \pm 2.05 b$ & $-47.08 \pm 4.52 \mathrm{~d}$ \\
\hline TC3 & $30.51 \pm 0.72 b$ & $56.03 \pm 2.20 \mathrm{~b}$ & $25.52 \pm 1.47 \mathrm{a}$ & $-27.60 \pm 1.59 b$ \\
\hline TC4 & $31.74 \pm 0.56 b$ & $50.04 \pm 0.23 c$ & $18.30 \pm 0.33 c$ & $-35.54 \pm 6.96 c$ \\
\hline TC5 & $20.73 \pm 1.68 c$ & $35.31 \pm 1.05 \mathrm{~d}$ & $14.58 \pm 2.73 d$ & $-37.25 \pm 6.96 c$ \\
\hline TC6 & $19.43 \pm 2.07 \mathrm{c}$ & $30.91 \pm 0.25 \mathrm{~d}$ & $11.48 \pm 1.82 \mathrm{~d}$ & $-10.57 \pm 1.68 \mathrm{a}$ \\
\hline GX1 & $33.82 \pm 0.13 \mathrm{a}$ & $57.70 \pm 2.16 \mathrm{a}$ & $23.88 \pm 2.04 \mathrm{ab}$ & $-50.36 \pm 4.29 \mathrm{e}$ \\
\hline GX2 & $27.04 \pm 2.81 b$ & $52.91 \pm 0.61 b$ & $25.87 \pm 2.20 \mathrm{a}$ & $-34.67 \pm 2.94 d$ \\
\hline GX3 & $23.08 \pm 0.45 c$ & $49.58 \pm 0.96 b c$ & $26.50 \pm 1.41 \mathrm{a}$ & $-30.54 \pm 1.62 c$ \\
\hline GX4 & $23.97 \pm 2.39 c$ & $45.82 \pm 3.61 \mathrm{c}$ & $21.85 \pm 1.22 b$ & $-25.80 \pm 1.44 b c$ \\
\hline GX5 & $22.88 \pm 1.98 \mathrm{~cd}$ & $43.32 \pm 1.45 c$ & $20.44 \pm 0.53 b$ & $-24.27 \pm 0.63 b c$ \\
\hline GX6 & $19.51 \pm 0.95 \mathrm{~d}$ & $30.89 \pm 2.02 \mathrm{e}$ & $11.38 \pm 1.07 \mathrm{~d}$ & $-22.42 \pm 2.10 b$ \\
\hline GX7 & $21.16 \pm 1.53 \mathrm{~cd}$ & $34.25 \pm 0.41 \mathrm{~d}$ & $13.09 \pm 1.12 \mathrm{c}$ & $-18.16 \pm 1.57 \mathrm{a}$ \\
\hline GX8 & $22.06 \pm 0.59 \mathrm{~cd}$ & $32.15 \pm 1.44 \mathrm{de}$ & $10.09 \pm 2.03 \mathrm{~d}$ & $-17.61 \pm 3.56 \mathrm{a}$ \\
\hline AX1 & $35.58 \pm 1.70 \mathrm{a}$ & $65.71 \pm 0.02 \mathrm{a}$ & $30.14 \pm 1.72 \mathrm{a}$ & $-64.57 \pm 3.70 \mathrm{~d}$ \\
\hline $\mathrm{AX} 2$ & $36.03 \pm 2.83 \mathrm{a}$ & $60.67 \pm 0.11 \mathrm{ab}$ & $24.64 \pm 2.72 b$ & $-52.16 \pm 5.76 c$ \\
\hline $\mathrm{AX} 3$ & $35.42 \pm 0.21 \mathrm{a}$ & $57.01 \pm 4.56 b$ & $21.59 \pm 4.36 b c$ & $-52.00 \pm 10.49 \mathrm{c}$ \\
\hline $\mathrm{AX} 4$ & $25.84 \pm 1.60 \mathrm{~b}$ & $48.34 \pm 0.71 \mathrm{c}$ & $22.49 \pm 2.31 b c$ & $-26.59 \pm 2.73 b$ \\
\hline AX5 & $22.34 \pm 1.65 b c$ & $40.66 \pm 0.12 \mathrm{~cd}$ & $18.32 \pm 1.53 \mathrm{c}$ & $-24.12 \pm 2.00 b$ \\
\hline AX6 & $19.51 \pm 0.44 d$ & $32.51 \pm 1.18 \mathrm{e}$ & $13.00 \pm 0.74 d$ & $-24.27 \pm 1.40 b$ \\
\hline $\mathrm{AX} 7$ & $19.32 \pm 0.31 \mathrm{~d}$ & $36.26 \pm 0.98 \mathrm{~d}$ & $16.94 \pm 0.68 \mathrm{~cd}$ & $-13.35 \pm 0.54 \mathrm{a}$ \\
\hline AX8 & $20.95 \pm 1.36 c$ & $32.48 \pm 1.36 \mathrm{e}$ & $11.53 \pm 0.02 \mathrm{e}$ & $-12.41 \pm 0.01 \mathrm{a}$ \\
\hline WH1 & $36.56 \pm 0.99 a$ & $62.70 \pm 1.04 \mathrm{a}$ & $26.14 \pm 0.05 \mathrm{a}$ & $-65.91 \pm 0.13 \mathrm{e}$ \\
\hline WH2 & $26.01 \pm 2.36 b$ & $52.20 \pm 0.97 b$ & $26.19 \pm 3.32 \mathrm{a}$ & $-31.84 \pm 4.03 b$ \\
\hline WH3 & $24.93 \pm 0.17 b c$ & $46.86 \pm 2.09 c$ & $21.93 \pm 1.92 b$ & $-42.67 \pm 3.74 d$ \\
\hline WH4 & $23.83 \pm 0.10 \mathrm{c}$ & $46.11 \pm 0.86 c$ & $22.28 \pm 0.96 b$ & $-38.60 \pm 1.68 b c d$ \\
\hline WH5 & $22.25 \pm 0.62 \mathrm{c}$ & $39.11 \pm 0.29 d$ & $16.87 \pm 0.33 \mathrm{c}$ & $-36.69 \pm 0.70 b c$ \\
\hline WH6 & $19.74 \pm 0.84 d$ & $34.22 \pm 1.95 \mathrm{e}$ & $14.48 \pm 1.11 \mathrm{~cd}$ & $-13.38 \pm 1.00 \mathrm{a}$ \\
\hline WH7 & $19.56 \pm 0.27 \mathrm{~d}$ & $30.77 \pm 1.32 \mathrm{f}$ & $11.21 \pm 1.59 \mathrm{~d}$ & $-11.65 \pm 1.63 \mathrm{a}$ \\
\hline WH8 & $18.91 \pm 1.44 \mathrm{~d}$ & $31.72 \pm 0.48 f$ & $12.81 \pm 1.93 \mathrm{~d}$ & $-12.24 \pm 1.85 \mathrm{a}$ \\
\hline
\end{tabular}

$62.68,57.70,65.71$ and $62.70 \%$ for the liquid limit, respectively). The plastic limit of the sandy soil layer and the detritus layer was significantly lower $(P<0.01)$ than that of the surface soil layer and the red soil layer, but with no significant difference between each other. As shown in Fig. 5, the soil Atterberg limits presented a nonlinear relationship with soil depth. Power function fitting showed that both the soil plastic limit and liquid limit had a remarkable negative correlation with the soil depth (Fig. 5a, $R^{2}=0.784, p<0.001$ and Fig. $5 \mathrm{~b}, R^{2}=0.877, p<0.0001$, respectively). Additionally, the soil plastic limit of the surface soil layer and the red soil layer ranged between 24.70 and $36.56 \%$ with an average of $31.98 \%$ and the liquid limit ranged between 49.43 and $65.71 \%$ with an average of $57.02 \%$, which are higher compared with most types of soil (Reznik, 2016), but an opposite trend was observed in the sandy soil layer and the detritus layer. Our findings are in agreement with the previous studies by Zhuang et al. (2014) and Xia et al. (2015), who reported that the topsoil layers have a better ability to resist deformation than the subsoil layers. These results indicate that the change in water content has little influence on the sur- face soil layer and the red soil layer, and the soil cannot be easily transformed into a liquid state by the rainfall erosion and runoff scouring. Conversely, the change in water content has a great influence on the sandy soil layer and the detritus layer, and with water content increasing, the soil can be changed from solid to liquid state.

\subsubsection{Soil plasticity index and liquidity index}

As shown in Table 4, there are considerable differences in soil plasticity index and liquidity index in the different weathering profiles of the four collapsing gullies. The soil plasticity index was highest in AX1 (30.14\%), followed by TC1 $(26.75 \%)$, GX3 $(26.50 \%)$ and $\mathrm{WH} 2(26.19 \%)$, and it was also the highest in each soil layer. However, the plasticity index was lowest in the bottom soil layers $(11.48,10.09$ and $11.53 \%$ for TC6, GX8 and AX8, respectively) except for WH. Additionally, inconsistent with plasticity index, liquidity index was the lowest in the surface soil layer of each weathering profile $(-49.55,-50.36,-64.57$ and $-65.91 \%$ for TC1, GX1, AX1 and WH1, respectively). The highest liquidity indexes of TC, GX, AX and WH were $-10.57 \%$ in 

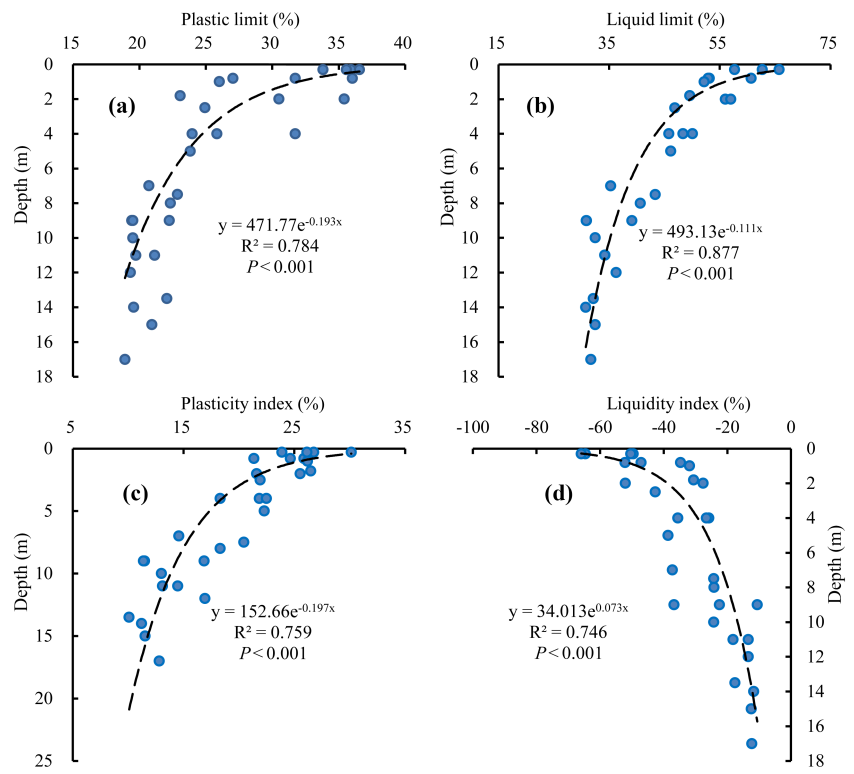

Figure 5. Relationship between soil Atterberg limits and soil depth. (a) Plastic limit, (b) liquid limit, (c) plasticity index and (d) liquidity index.

TC6, $-17.61 \%$ in GX8, $-12.41 \%$ in AX8 and $-11.65 \%$ in WH7, respectively. Figure $4 \mathrm{a}-\mathrm{d}$ summarizes the statistics of soil plasticity index and liquidity index in all of the different weathering profiles. Significant differences were observed in all the measured plasticity and liquidity indexes between the surface soil layer, red soil layer, sandy soil layer and the detritus layer. The results indicated that the soil plasticity index decreased noticeably with the decline of weathering degree (from the surface layer to detritus layer), which is similar to the variation regularity of plastic limit and liquid limit.

The surface layer of the TC, AX and WH collapsing gullies had the greatest soil plasticity index $(26.75,30.14$ and $26.14 \%$, respectively), but the greatest plasticity index $(23.88 \%)$ of the GX collapsing gully was found in the red soil layer. In contrast with the plasticity index, the liquidity index was significantly $(P<0.01)$ higher in the sandy soil layer and the detritus layer and was the lowest in the surface soil layer $(-49.55,-50.36,-64.57$ and $-65.91 \%$ for $\mathrm{TC}$, GX, AX and WH, respectively; Fig. 4). Regression analyses were performed to determine the strength of relationships between the plasticity index, the liquidity index and soil depth (Fig. 5a-d). The nonlinear regression analyses showed that the plasticity index had a remarkable negative correlation with the soil depth (Fig. $5 \mathrm{c}, R^{2}=0.759, P<0.001$ ). However, there was a significant positive correlation between the soil liquidity index and the soil depth based on the power function fitting analysis (Fig. $5 \mathrm{~d}, R^{2}=0.746, P<0.001$ ).

The differences in soil plasticity index and liquidity index between topsoil layers and subsoil layers may be related to the variation in the dynamics of the soil properties. As previously reported, changes in soil plasticity index and liquidity index depend on soil properties such as clay and organic matter (Zhuang et al., 2014). The size of the plasticity index is directly related to the maximum possible bound water content of a certain mass of soil particles. However, the bound water content of soil is related to the size of soil particle, mineral composition, the composition and concentration of cation in the hydration membrane. Thus, the plasticity index is a comprehensive indicator for the reaction properties of clayey soil, which means the larger the index is, the higher the clay content will be (Husein et al., 1999). Our findings clearly demonstrated that the plasticity index of subsoil layers was significantly lower $(P<0.01)$ than that of topsoil layers in the different weathering profiles, implying that the content of fine particles in the soil gradually decreased with soil depth. Previous studies about soil texture classification are frequently based on soil plasticity index: a soil with a value between 10 and $17 \%$ is defined as silty clay and that with a value greater than $17 \%$ is classified as clay (Zentar et al., 2009; Marek et al., 2015). Based on this classification theory, most topsoil layers in the TC, GX, AX and WH collapsing gullies can be defined as clay, while the subsoil layers can be classified as silty clay, which is more susceptible to erosion.

However, the adsorption capacity of bound water varied under a different soil specific surface area and mineral composition. Therefore, given the same water content, for the soil with high viscosity, the water may be bound water, while for the soil with low viscosity, a considerable part of the water can be free water, which means that the soil state cannot be defined only by water content and we need another indicator, namely the liquidity index, to reflect the relationship between natural water content and Atterberg limits in the soil. The liquidity index is defined as the ratio of the difference between the natural moisture content and the plastic limit to the plastic limit (Sposito, 1989). When the natural moisture content is close to the plastic limit, the soil is hard; when it is close to the liquid limit, the soil is weak in cohesive strength. In engineering practice, the soil is in a hard state when the liquidity index is less than 0 (Zhuang et al., 2014). In our research, the liquidity indexes of all soils were less than 0 , indicating that the soil of the different weathering profiles of the four collapsing gullies is hard in the natural state. Nevertheless, the subsoil layers of the collapsing gullies are more close to 0 than the topsoil layers in the liquidity index, indicating that the subsoil layers are weaker than the topsoil layers in cohesion strength.

\subsubsection{Relationship between soil Atterberg limits and collapsing gully}

In this study, the liquidity indexes of all soils were less than 0 , indicating that the soils of the four collapsing gullies remain solid in natural state, with a high shear strength and strong resistance to water erosion, enabling the soil of granite weathering profile to maintain stability. From the soil Atterberg limits of all the soils, it can be seen that the plastic limit, 
liquid limit and plasticity index are higher in the surface soil layer and red soil layer, implying that the plastic state cannot be easily changed when the rain lasts a short time, such as moderate to light rain, which usually does not lead to the collapse and loss of the soils with high compaction and hardness. However, if the rainfall duration is long enough, the soil water content can reach a high level, leading to an increase in the soil self-weight, a decrease in the soil shear strength, and thus the collapse of the soils. The plastic limit, liquid limit and plasticity index of the sandy soil layer and detritus layer are significantly smaller than those of the surface soil layer and red soil layer, indicating that it is very easy for the soils in the sandy soil layer and detritus layer to reach the plastic limit in the case of short-term rainfall, and coupled with the looser soil and smaller soil shear strength, it is easy for them to collapse.

Because of the lower soil Atterberg limits of the collapsing gully in the subsoil layers, soil moisture absorption leads to the increase in water content after a long period of rain erosion and soil preferential flow. The sandy soil layer and detritus layer of the collapsing gully would be the first to reach or close to the plastic state in the same moisture conditions. Meanwhile, the shear strength of the two soil layers decreased rapidly, leading to the formation of the weak surface and then collapse or water erosion. The erosion is much more severe in the sandy soil layer and detritus layer than in the surface soil layer and red soil layer, resulting in the hollowing-out of the subsoil layers and the formation of a concave pit called "niche" in the engineering geology (Ding et al., 1995; Deng et al., 2016b). The formation and development of the niche is the preliminary stage of the formation of a collapsing gully. After niche formation, the surface soil layer and red soil layer lack support, giving rise to a total collapse by the soil self-weight. The occurrence of collapse forms the source of erosion, resulting in the formation of the collapsing gully.

In addition, as can be seen from Table 5, soil Atterberg limits of different weathering profiles of the Quaternary red clay are very different from those of granite soil, an Ultisol in southern China. The plastic limit, liquid limit, plasticity index and liquidity index of the Quaternary red clay show an upward trend first and then a downward trend. However, these values of the topsoil layers (A layer and B layer) are similar to those of the surface layer and red soil layer of granite, while the values of subsoil layers (C1 layer and $\mathrm{C} 2$ layer) are significantly higher than those of the sandy soil layers and detritus layers of granite. Therefore, under the condition of rainfall, even if the profile of the Quaternary red soil is exposed, the subsoil layers are not easy to be eroded. Purely because of these properties, the formation of a "niche" is difficult for the soil profile of the Quaternary red clay, and thus few collapsing gullies occurred in the Quaternary red clay. However, the stratigraphic characteristics of the soil Atterberg limits are particularly significant for granite soil, and the collapsing gully is most likely to occur on this parent ma- terial in the hilly region of southern China. There are many factors responsible for the occurrence of the collapsing gully (soil thickness, vegetation, climate, etc.), and soil Atterberg limits of different weathering profiles of granite soil may be just one of the necessary, rather than sufficient, conditions for the development of the collapsing gully. This will be further studied in the future work.

\subsection{Effect of soil physicochemical properties on soil Atterberg limits}

In this research, we examined the soil particle density (PD), bulk density (BD), total porosity (TP), soil organic matter (SOM), cation exchange capacity (CEC), free iron oxide $\left(\mathrm{Fe}_{\mathrm{d}}\right)$ and particle-size distribution (PSD) in the different soil layers of the four collapsing gullies (TC, GX, AX and $\mathrm{WH}$ ). The relationships between soil physicochemical properties and soil Atterberg limits are shown in Table 4.

\subsubsection{Soil particle density (PD), bulk density (BD) and total porosity (TP)}

Regression analyses were performed to determine the strength of relationships between Atterberg limits and soil particle density, bulk density and total porosity in the soils of the four collapsing gullies (TC, GX, AX and WH). Specifically, soil Atterberg limits had a very weak negative correlation with the soil BD $\left(R^{2}=0.044, P=0.273\right.$ for plastic limit; $R^{2}=0.021, P=0.450$ for liquid limit) and PD $\left(R^{2}=0.023, P=0.423\right.$ for plastic limit; $R^{2}=0.002$, $P=0.818$ for liquid limit), and a very weak positive correlation with the soil TP $\left(R^{2}=0.124, P=0.057\right.$ for plastic limit; $R^{2}=0.077, P=0.139$ for liquid limit). Therefore, there was almost no significant correlation between soil Atterberg limits and PD, BD and TP in the soils of the four collapsing gullies.

\subsubsection{Soil organic matter (SOM)}

In Table 6, regression analyses showed that the soil organic matter had a significant and positive correlation with plastic limit $\left(R^{2}=0.816, P<0.001\right)$ and liquid limit $\left(R^{2}=0.785\right.$, $P<0.001)$. This is probably because soil organic matter can promote organic colloid formation to affect the specific surface area, the water holding capacity of the soil particles and thus the soil liquid limit (Stanchi et al., 2012). With the increase in organic matter content, organic colloid also increased, implying that the greater the water holding capacity of the soil is, the greater the liquid limit will be. In this research, the soil Atterberg limits had a significant positive correlation with the organic matter. Similar results were also reported by Zhuang et al. (2014) and Husein et al. (1999), who both concluded that the plastic limit and the liquid limit of the soil increase with increasing organic content. According to the relationship between the Atterberg limits and the organic matter in the weathering profiles of granite soil, we 
Table 5. Soil Atterberg limits of different weathering profiles of the Quaternary red clay in Xianning.

\begin{tabular}{lrrrr}
\hline Soil layer & Plastic limit $(\%)$ & Liquid limit $(\%)$ & Plasticity index (\%) & Liquidity index (\%) \\
\hline A & $31.76 \pm 0.11 \mathrm{~b}$ & $52.21 \pm 0.15 \mathrm{~b}$ & $20.45 \pm 0.26 \mathrm{a}$ & $-71.10 \pm 0.91 \mathrm{c}$ \\
B & $35.37 \pm 3.10 \mathrm{a}$ & $56.16 \pm 2.19 \mathrm{a}$ & $20.79 \pm 0.91 \mathrm{a}$ & $-77.14 \pm 3.39 \mathrm{~b}$ \\
C1 & $28.80 \pm 1.15 \mathrm{bc}$ & $48.16 \pm 2.78 \mathrm{c}$ & $19.37 \pm 1.64 \mathrm{~b}$ & $-54.23 \pm 4.59 \mathrm{a}$ \\
C2 & $26.67 \pm 0.61 \mathrm{c}$ & $45.54 \pm 0.38 \mathrm{~d}$ & $18.87 \pm 0.24 \mathrm{~b}$ & $-51.91 \pm 0.65 \mathrm{a}$ \\
\hline
\end{tabular}

Table 6. Regression and correlation analyses of soil Atterberg limits with soil physicochemical properties.

\begin{tabular}{|c|c|c|c|c|c|c|}
\hline & \multicolumn{3}{|l|}{ Plastic limit } & \multicolumn{3}{|l|}{ Liquid limit } \\
\hline & Regression equations & $R^{2}$ & $P$ & Regression equations & $R^{2}$ & $P$ \\
\hline Gravel content & $y=-5.083 \ln (x)+38.722$ & 0.258 & 0.004 & $y=-8.323 \ln (x)+66.423$ & 0.219 & 0.009 \\
\hline Coarse sand content & $y=-8.895 \ln (x)+48.448$ & 0.208 & 0.011 & $y=-21.66 \ln (x)+100.51$ & 0.362 & $<0.001$ \\
\hline Fine sand content & $y=-4.772 \ln (x)+38.804$ & 0.155 & 0.031 & $y=-9.633 \ln (x)+71.562$ & 0.178 & 0.020 \\
\hline Sand content & $y=-17.16 \ln (x)+90.809$ & 0.569 & $<0.001$ & $y=-32.52 \ln (x)+168.51$ & 0.644 & $<0.001$ \\
\hline Silt content & $y=-19.2 \ln (x)+91.772$ & 0.314 & 0.001 & $y=-28.59 \ln (x)+143.51$ & 0.213 & 0.010 \\
\hline Clay content & $y=7.6773 \ln (x)+3.4506$ & 0.795 & $<0.001$ & $y=14.915 \ln (x)+1.8834$ & 0.827 & $<0.001$ \\
\hline $\mathrm{BD}$ & $y=-28.04 \ln (x)+34.789$ & 0.044 & 0.273 & $y=-35.65 \ln (x)+56.651$ & 0.021 & 0.450 \\
\hline PD & $y=-49.17 \ln (x)+73.088$ & 0.023 & 0.423 & $y=-27.35 \ln (x)+71.436$ & 0.002 & 0.818 \\
\hline $\mathrm{TP}$ & $y=35.364 \ln (x)-110.82$ & 0.124 & 0.057 & $y=51.702 \ln (x)-154.49$ & 0.077 & 0.139 \\
\hline SOM & $y=4.2553 \ln (x)+22.753$ & 0.816 & $<0.001$ & $y=7.6856 \ln (x)+39.781$ & 0.785 & $<0.001$ \\
\hline CEC & $y=7.9009 \ln (x)+11.719$ & 0.657 & $<0.001$ & $y=15.682 \ln (x)+17.359$ & 0.767 & $<0.001$ \\
\hline $\mathrm{Fe}_{\mathrm{d}}$ & $y=10.629 \ln (x)-4.226$ & 0.688 & $<0.001$ & $y=21.885 \ln (x)-16.509$ & 0.837 & $<0.001$ \\
\hline
\end{tabular}

can conclude that the higher the content of organic matter is, the stronger the anti-erodibility of the soil will be. Thus, our research provides a theoretical basis for the prevention and control of collapsing gully by using green manure to improve soil organic matter in these areas.

\subsubsection{Cation exchange capacity (CEC)}

As shown in Table 6, there was a strong positive correlation between soil Atterberg limits and CEC $\left(R^{2}=0.657\right.$, $P<0.001$ for plastic limit; $R^{2}=0.767, P<0.001$ for liquid limit). Similar results were reported by Cathy et al. (2008), who proposed that CEC can be used as an indicator for the mineral type and that it is highly correlated with plastic limit and liquid limit.

\subsubsection{Free iron oxide $\left(\mathrm{Fe}_{\mathrm{d}}\right)$}

A positive significant correlation was observed between soil Atterberg limits and Fed $\left(R^{2}=0.688, P<0.001\right.$ for plastic limit; $R^{2}=0.837, P<0.001$ for liquid limit; Table 6$)$. This is consistent with the finding of Stanchi (2015), who reported that Atterberg limits were also affected by CEC. Therefore, $\mathrm{Fe}_{\mathrm{d}}$ acts as an inorganic binding agent in structure formation and participates in reducing horizon vulnerability, as proposed by Sposito (1989).

\subsubsection{Particle-size distribution (PSD)}

Regression analyses were performed to determine the strength of relationships between soil Atterberg limits and the contents of gravel, coarse sand, fine sand, silt and clay in the soils of collapsing gullies (Table 6). The nonlinear regression analyses showed a strong positive correlation of the soil Atterberg limits with the clay content $\left(R^{2}=0.795\right.$, $P<0.001$ for plastic limit; $R^{2}=0.827, P<0.001$ for liquid limit), a remarkable negative correlation with the content of sand $\left(R^{2}=0.569, P<0.001\right.$ for plastic limit; $R^{2}=0.644$, $P<0.001$ for liquid limit) and a weak negative correlation with the silt content $\left(R^{2}=0.314, P=0.001\right.$ for plastic limit; $R^{2}=0.213, P=0.010$ for liquid limit), gravel content $\left(R^{2}=0.258, P=0.004\right.$ for plastic limit; $R^{2}=0.219$ $P=0.009$ for liquid limit), coarse sand content $\left(R^{2}=0.208\right.$, $P=0.011$ for plastic limit; $R^{2}=0.362, P<0.001$ for liquid limit) and fine sand content $\left(R^{2}=0.155, P=0.031\right.$ for plastic limit; $R^{2}=0.178, P=0.020$ for liquid limit). The significant negative correlation between soil Atterberg limits and sand may be attributed to porosity and specific surface area. When the sand content increases, the soil pores will increase and surface area will decrease, resulting in poor soil performance and facilitating water movement. Meanwhile, sandy soil is low in viscosity, loose and difficult to expand, leading to the slow rise of capillary water during water erosion. Therefore, the soil plastic limit and liquid limit will decrease with increasing sand content. Our results show that with de- 
clining weathering degree, the sand increased and the finer soil particles declined, which causes the decrease in soil Atterberg limits, and the subsoil layers are the first to be eroded (Zhuang et al., 2014).

Furthermore, there was a significant positive correlation between soil Atterberg limits and clay content, indicating that the clay content, despite its modest amount, plays a major role in determining the values of plastic limit and liquid limit. This also shows that, in the weathering profiles, the soil Atterberg limits increased with the increase in clay content, which is also reported by several other studies (Polidori, 2007; Baskan et al., 2009; Keller and Dexter, 2012). This result may be due to the effect of clay on soil plasticity in changing the arrangement of soil particles and cation exchange capacity. The connection form, the arrangement of soil particles and soil pore size will vary greatly with the clay content. Additionally, soil clay has a larger specific surface area, which will affect the soil water storage capacity. Therefore, the huge specific surface area enables the clay to have strong adsorption capacity, which affects the speed of water flow in the soil. Meanwhile, the mosaic of clay particles to the larger pores can also block the flow channels in the soil. All of these will affect the soil Atterberg limits, with the high clay content contributing to the directional arrangement of soil particles, leading to the increase in weakly bound water content, thereby increasing the plastic limit and liquid limit of the soil.

Overall, soil is a sphere of the earth system with a special structure and function. From the point of view of the earth system, soil science should not only study the soil material but also change towards the relationship between the soil and the earth system, which has a profound impact on the human living environment and global change research (Brevik et al., 2015; Keesstra et al., 2016). The results show that the relationship between soil Atterberg limits and the occurrence mechanism of collapsing gully, which can be used as a reference for the assessment of natural disasters occurring in the interaction between water and force in nature.

\section{Conclusions}

Based on the analyses of soil Atterberg limits, soil physicochemical properties, the influence factors on collapsing gully and the relationships between soil Atterberg limits and soil physicochemical properties of different weathering profiles of the four collapsing gullies in the hilly granitic region, the conclusions are summarized as follows.

Different weathering profiles exhibit a significant effect on soil Atterberg limits and soil physicochemical properties. The topsoil layers show the highest plastic limit, liquid limit, plasticity index, $\mathrm{SOM}, \mathrm{CEC}$ and $\mathrm{Fe}_{\mathrm{d}}$; finer soil particles; and the lowest liquidity index, PD, and BD. As weathering degree decreases (from the surface layer to detritus layer), there is a sharp decrease in the plastic limit, liquid limit, plasticity index, $\mathrm{SOM}, \mathrm{CEC}$ and $\mathrm{Fe}_{\mathrm{d}}$; a gradual increase in liquidity index; and a sharp increase in PD and BD first, followed by a slight decline. Additionally, the finer soil particles (silt and clay) decrease, and especially the clay contents decline noticeably, whereas the gravel and sand contents increase considerably. Therefore, the soils of subsoil layers very easily reach the soil Atterberg limits during rain, and coupled with the looser soil structure, it is easy for them to be eroded, resulting in the hollowing-out of these soil layers and the formation of a concave pit called a "niche" in engineering geology. After the niche formation, the topsoil layers lack support, leading to a total collapse in the soil by the soil selfweight and causing the formation of the collapsing gully. The regression analysis shows that soil Atterberg limits are significantly positively correlated with SOM, clay content, CEC and $\mathrm{Fe}_{\mathrm{d}}$; remarkably negatively correlated with sand content; and not obviously correlated with other properties. The results of this study demonstrate that soil Atterberg limits can be regarded as an informative indicator to reflect the weathering degree of different weathering profiles of the collapsing gully. Future research will include the relationship between soil Atterberg limits and soil mechanical properties.

Author contributions. Conceived and designed the experiments: Yusong Deng, Chongfa Cai and Jiazhou Chen. Performed the experiments: Yusong Deng and Dong Xia. Analyzed the data: Yusong Deng. Contributed reagents/materials/analysis tools: Yusong Deng, Dong Xia and Shuwen Ding. Wrote the paper: Yusong Deng, Chongfa Cai, Dong Xia, Shuwen Ding Jiazhou Chen and Tianwei Wang.

Competing interests. The authors declare that they have no conflict of interest.

Acknowledgements. Financial support for this research was provided by the National Natural Science Foundation of China (no. 41630858; 41601287 and 41571258) and National Science and technology basic work project (no. 2014 FY110200A16). We would like to thank several anonymous reviewers for their valuable comments on a previous version of the manuscript.

Edited by: M. Muñoz-Rojas

Reviewed by: F. Pacheco and three anonymous referees

\section{References}

Anderson, J. M. and Ingram, J. S. I.: Tropical soil biology and fertility: a handbook of methods, Soil Sci., 157, 12-21, 1994.

Archer, J. R.: Soil consistency, in: Soil Physical Conditions and Crop Production, Ministry of Agriculture, Fisheries and Food, Tech. Bull., London: HMSO, 29, 289-297, 1975.

Arjmand Sajjadi, S. and Mahmoodabadi, M.: Aggregate breakdown and surface seal development influenced by rain intensity, 
slope gradient and soil particle size, Solid Earth, 6, 311-321, doi:10.5194/se-6-311-2015, 2015.

ASTMD 4318-10e1: Standard Test Methods for Liquid Limit, Plastic Limit, and Plasticity Index of Soils, ASTM International, West Conshohocken, PA, 2010.

Atterberg, A.: Die plastizität der tone, Internationale Mitteilungen für Bodenkunde, 1, 10-43, 1911.

Baskan, O., Erpul, G., and Dengiz, O.: Comparing the efficiency of ordinary Kriging and cokriging to estimate the Atterberg limits spatially using some soil physical properties, Clay Miner., 44, 181-193, 2009.

Baver, L. D.: The Atterberg consistency constants: Factors affecting their values and a new concept of their significance, J. Am. Soc. Agron., 22, 935-948, 1930.

Brevik, E. C., Cerdà, A., Mataix-Solera, J., Pereg, L., Quinton, J. N., Six, J., and Van Oost, K.: The interdisciplinary nature of SOIL, SOIL, 1, 117-129, doi:10.5194/soil-1-117-2015, 2015.

Campbell, D. J.: Liquid and plastic limits, in: Soil and environmental analysis-physical methods, edited by: Smith, K. A. and Mullins, C. E., Dekker Inc., New York, 349-375, 2001.

Casagrande, A.: Research on the Atterberg limits of soils, Public Roads, 13, 121-136, 1932.

Casagrande, A.: Notes on the design of the liquid limit device, Geáotechnique, 8, 84-91, 1958.

Cerdà, A.: The effect of season and parent material on water erosion on highly eroded soils in eastern Spain, J. Arid Environ., 52, 319337, 2002.

Cerdà, A. and Doerr, S. H.: Soil wettability, runoff and erodibility of major dry-Mediterranean land use types on calcareous soils, Hydrol. Process., 21, 2325-2336, 2007.

Curtaz, F., Stanchi, S., D’Amico, M. E., Filippa, G., Zanini, E., and Freppaz, M.: Soil evolution after land-reshaping in mountains areas (Aosta Valley, NW Italy), Agr. Ecosyst. Environ., 199, 238 248, 2015

Deng, Y. S., Ding, S. W., Liu, C. M., Xia, D., Zhang, X. M., and Lv, G. A.: Soil moisture characteristics of collapsing gully wall in granite area of southeastern Hubei, J. Soil Water Conserv., 29, 132-137, 2015 (in Chinese).

Deng, Y. S., Ding, S. W., Cai, C. F., and Lv, G. A.: Characteristic curves and model analysis of soil moisture in collapse mound profi les in southeast Hubei, Acta Pedologica Sinica, 53, 355364, 2016a (in Chinese).

Deng, Y. S., Xia, D., Cai, C. F., and Ding, S. W.: Effects of land uses on soil physic-chemical properties and erodibility in collapsinggully alluvial fan of Anxi County, China, J. Integr. Agr., 15, 1863-1873, 2016b.

Deng, Y. S., Cai, C. F., Xia, D., Ding, S. W, ang Chen, J. Z.: Fractal features of soil particle size distribution under different land-use patterns in the alluvial fans of collapsing gullies in the hilly granitic region of southern China, Plos one, 12, e0173555, doi:10.1371/journal.pone.0173555, 2017.

Ding, S. W., Cai, C. F., and Zhang, G. Y.: A study on gravitational erosion and the formation of collapsing gully in the granite area of Southeast Hubei, Journal of Nanchang College of Water Conservancy and Hydroelectric Power, S1, 50-54, 1995 (in Chinese).

Feng, M. H., Liao, C. Y., Li, S. X., and Lu, S. L.: Investigation on the present situation of collapsing gully in the south of China, People Yangtze River, 40, 66-68, 2009 (in Chinese).
Gee, G. W. and Bauder, J. W.: Particle size analysis, in: Methods of Soil Analysis, Part 1, Agronomy, edited by: Klute, A., Am. Soc. Agron. Inc., Madison, Wis, 9, 1986.

Hemmat, A., Aghilinategh, N., and Rezainejad, Y.: Long-term impacts of municipal solid waste compost, sewage sludge and farmyard manure application on organic carbon, bulk density and consistency limits of a calcareous soil in central Iran, Soil Till. Res., 108, 43-50, 2010.

Hillel, D.: Fundamentals of Soil Physics, Academic Press: New York, 1980.

Huang, B., Li, Z. W., Huang, J. Q., Liang, G., Nie, X. D., Wang, Y, Zhang, Y., and Zeng, G. M.: Adsorption characteristics of $\mathrm{Cu}$ and $\mathrm{Zn}$ onto various size fractions of aggregates from red paddy soil, J. Hazard. Mater., 264, 176-183, 2014.

Husein Malkawi, A. I., Alawneh, A. S., and Abu, O. T.: Effects of organic matter on the physical and the physicochemical properties of an illitic soil, Appl. Clay Sci., 14, 257-278, 1999.

Jiang, F. S., Huang, Y. H., Wang, M. K., Lin, J. S., Zhao, F., and Ge, H. L.: Effects of rainfall intensity and slope gradient on steep colluvial deposit erosion in southeast China, Soil Sci. Soc. Am. J., 78, 1741-1752, 2014.

Jong, E. D., Acton, D. F., and Stonehouse, H. B.: Estimating the Atterberg limits of southern Saskatchewan soils from texture and carbon contents, Can. J. Soil Sci., 70, 543-554, 1990.

Jordán, A., Zavala, L. M., Nava, A. L., and Alanís, N.: Occurrence and hydrological effects of water repellency in different soil and land use types in Mexican volcanic highlands, Catena, 79, 60-71, 2009.

Jordán, A., Ángel, J., Gordillo-Rivero, García-Moreno, J., Zavala, L. M., Granged, A. J. P., Gil, J., and Neto-Paixão, H. M.: Post-fire evolution of water repellency and aggregate stability in Mediterranean calcareous soils: a 6-year study, Catena, 118, 115-123, 2014.

Keesstra, S. D., Bouma, J., Wallinga, J., Tittonell, P., Smith, P., Cerdà, A., Montanarella, L., Quinton, J. N., Pachepsky, Y., van der Putten, W. H., Bardgett, R. D., Moolenaar, S., Mol, G., Jansen, B., and Fresco, L. O.: The significance of soils and soil science towards realization of the United Nations Sustainable Development Goals, SOIL, 2, 111-128, doi:10.5194/soil-2-1112016, 2016.

Keller, T. and Dexter, A. R.: Plastic limits of agricultural soils as functions of soil texture and organic matter content, Soil Res., 50, 7-17, 2012.

Khaledian, Y., Kiani, F., Ebrahimi, S., Brevik, E. C., and Aitkenhead-Peterson, J.: Assessment and monitoring of soil degradation during land use change using multivariate analysis, Land Degrad. Dev., 128-141, doi:10.1002/ldr.2541, 2016.

Lan, H. X., Hu, R. L., Yue, Z. Q., Lee, C. F., and Wang, S. J.: Engineering and geological characteristics of granite weathering profiles in South China, J. Asian Earth Sci., 21, 353-364, 2003.

Lee, S. B., Chang, H. L., Jung, K. Y., Park, K. D., Lee, D., and Kim, P. J.: Changes of soil organic carbon and its fractions in relation to soil physical properties in a long-term fertilized paddy, Soil Till. Res., 104, 227-232, 2009.

Li, S. P.: Study on erosion law and control of slope disintegration in Guangdong province, Journal of Natural Disasters, 3, 68-74, 1992 (in Chinese). 
Liang, Y., Ning, D. H., Pan, X. Z., Li, D. C., and Zhang, B.: Characteristics and treatment of collapsing gully in red soil region of southern China, Soil Water Conserv. China, 1, 31-34, 2009.

Lin, J. S., Huang, Y. H., Wang, M. K., Jiang, F. S., Zhang, X., and Ge, H.: Assessing the sources of sediment transported in gully systems using a fingerprinting approach: An example from South-east China, Catena, 129, 9-17, 2015.

Liu, X. L. and Zhang, D. L.: Distribution Characteristics and spatial variation of Benggang soil moistures: A case study of Liantanggang in Wuhua County, Guangdong, Tropical Geography, 35, 291-297, 2015 (in Chinese).

Luk, S. H., Yao, Q. Y., Gao, J. Q., Zhang, J. Q., He, Y. G., and Huang, S. M.: Environmental analysis of soil erosion in Guangdong province: a Deqing case study, Catena, 29, 97-113, 1997a.

Luk, S. H., Dicenzo, P. D., and Liu, X. Z.: Water and sediment yield from a small catchment in the hilly granitic region, South China, Catena, 29, 177-189, 1997b.

Marek, S. Ż., Williams, D. J., Song, Y.-F., and Wang, C.-C.: Smectite clay microstructural behaviour on the Atterberg limits transition, Colloid. Surface. A, 467, 89-96, 2015.

Masto, R. E., Sheik, S., Nehru, G., Selvi, V. A., George, J., and Ram, L. C.: Assessment of environmental soil quality around Sonepur Bazari mine of Raniganj coalfield, India, Solid Earth, 6, 811821, doi:10.5194/se-6-811-2015, 2015.

McBride, R. A.: Soil consistency and lower plastic limits, in: Soil Sampling and Methods of Analysis, edited by: Carter, M. R. and Gregorich, E. G., 2nd Edn., CRC Press, 58, 761-769, 2008.

Mehra, O. P. and Jackson, M. L.: Iron oxide removal from soils and clays by a dithionite-citrate system buffered with sodium bicarbonate, Clay. Clay Miner., 7, 317-327, 1958.

Moreno-Ramón, H., Quizembe, S. J., and Ibáñez-Asensio, S.: Coffee husk mulch on soil erosion and runoff: experiences under rainfall simulation experiment, Solid Earth, 5, 851-862, doi:10.5194/se-5-851-2014, 2014.

Muñoz-Rojas, M., Erickson, T. E., Dixon, K. W., and Merritt, D. J.: Soil quality indicators to assess functionality of restored soils in degraded semiarid ecosystems, Restor. Ecol., 24, S43-S52, 2016a.

Muñoz-Rojas, M., Erickson, T. E., Martini, D., Dixon, K. W., and Merritt, D. J.: Soil physicochemical and microbiological indicators of short, medium and long term post-fire recovery in semiarid ecosystems, Ecol. Indic., 63, 14-22, 2016 b.

Nelson, D. W. and Sommers, L. E.: Total carbon, organic carbon, and organic matter, Methods of Soil Analysis Part-chemical Methods, 1982.

Oliveira, S. P. D., Lacerda, N. B. D., Blum, S. C., Escobar, M. E. O., and Oliveira, T. S. D.: Organic carbon and nitrogen stocks in soils of northeastern Brazil converted to irrigated agriculture, Land Degrad. Dev., 26, 9-21, 2015.

Peng, F., Quangang, Y., Xue, X., Guo, J., and Wang, T.: Effects of rodent-induced land degradation on ecosystem carbon fluxes in an alpine meadow in the Qinghai-Tibet Plateau, China, Solid Earth, 6, 303-310, doi:10.5194/se-6-303-2015, 2015.

Perrin, A. S., Fujisaki, K., Petitjean, C., Sarrazin, M., Godet, M., Garric, B., and Brossard, M.: Conversion of forest to agriculture in Amazonia with the chop-and-mulch method: does it improve the soil carbon stock?, Agr. Ecosyst. Environ., 184, 101-114, 2014.
Polidori, E.: Relationship between the Atterberg limits and clay content, Soils Found., 47, 887-896, 2007.

Qiu, S. J.: The process and mechanism of red earth slope disintegration erosion, Bulletin of Soil and Water Conservation, 6, 31-40, 1994 (in Chinese).

Rashid, A. S. A., Kalatehjari, R., Noor, N. M., Yaacob, H., Moayedi, H., and Sing, L. K.: Relationship between liquidity index and stabilized strength of local subgrade materials in a tropical area, Measurement, 55, 231-237, 2014.

Reznik, Y. M.: Relationship between plastic limit values and fine fractions of soils, Geotechnical and Geological Engineering, 34, 403-410, 2016.

Rhoades, J. D.: Cation exchange capacity, in: Methods of Soil Analysis, Part 2, Chemical and Microbiological Properties, edited by: Page, A. L., 2nd Edn., Agronomy 9, ASA, SSSA, Madison, WI, USA, 149-157, 1982.

Seybold, C. A., Elrashidi, M. A., and Engel, R. J.: Linear regression models to estimate soil liquid limit and plasticity index from basic soil properties, Soil Sci., 173, 25-34, 2008.

Shahminan, D. N. I. A. A., Rashid, A. S. A., Bunawan, A. R., Yaacob, H., and Noor, N. M.: Relationship between strength and liquidity index of cement stabilized laterite for subgrade application, Int. J. Soil Sci., 9, 16-21, 2014.

Sharma, B. and Bora, P. K.: A study on correlation between liquid limit, plastic limit and consolidation properties of soils, Indian Geotechnical Journal, 45, 1-6, 2015.

Sheng, J. A. and Liao, A. Z.: Erosion control in south China, Catena, 29, 211-221, 1997.

S.I.S.S.: in: Angeli Milano, edited by: Angeli, F., Metodi di analisi fisica del suolo, Ministero per le Politiche Agricole, Rome (Italy), 1997.

Sposito, G.: The Chemistry of Soils, Oxford Univ. Press, New York, 1989.

Stanchi, S., Freppaz, M., and Zanini, E.: The influence of Alpine soil properties on shallow movement hazards, investigated through factor analysis, Nat. Hazards Earth Syst. Sci., 12, 18451854, doi:10.5194/nhess-12-1845-2012, 2012.

Stanchi, S., D’Amico, M., Zanini, E., and Freppaz, M.: Liquid and plastic limits of mountain soils as a function of the soil and horizon type, Catena, 135, 114-121, 2015.

Vacchiano, G., Stanchi, S., Ascoli, D., Marinari, G., Zanini, E., and Motta, R.: Soil-mediated effects of fire on Scots pine (Pinussylvestris L.) regeneration in a dry, inner-alpinevalley, Sci. Total Environ., 472, 778-788, 2014.

Wang, Y. H., Xie, X. D., and Wang, C. Y.: Formation mechanism of calamities due to Benggang processes of weathered granitic rocks, J. Mountain Sci., 6, 496-501, 2000.

Wroth, C. P. and Wood, D. M.: The correlation of index properties with some basic engineering properties of soils, Can. Geotech. J., 15, 137-145, 1978.

Xia, D., Deng, Y. S., Wang, S. L., Ding, S. W., and Cai, C. F.: Fractal features of soil particle-size distribution of different weathering profiles of the collapsing gullies in the hilly granitic region, South China, Nat. Hazards, 79, 455-478, 2015.

Xia, D., Ding, S. W., Long, L., Deng, Y. S., Wang, Q. X., Wang, S. L., and Cai, C. F.: Effects of collapsing gully erosion on soil qualities of farm fields in the hilly granitic region of south China, J. Integr. Agr., 15, 2873-2885, 2016. 
$\mathrm{Xu}$, J. X.: Benggang erosion: the influencing factors, Catena, 27, 249-263, 1996.

Yalcin, A.: The effects of clay on landslides: a case study, Appl. Clay Sci., 38, 77-85, 2007.

Zeng, Z. X.: Rock topography, Geological Publishing House, 1980 (in Chinese).

Zentar, R., Abriak, N. E., and Dubois, V.: Effects of salts and organic matter on Atterberg limits of dredged marine sediments, Appl. Clay Sci., 42, 391-397, 2009.

Zhang, S. and Tang, H. M. Experimental study of disintegration mechanism for unsaturated granite residual soil, Rock and Soil Mechanics, 6, 1668-1674, 2013 (in Chinese).

Zhang, X. J.: The practice and prospect of hill collapsing improving and development in southern China, China Water Resource, 4, 17-22, 2010 (in Chinese).

Zhang, X. M., Ding, S. W., and Cai, C.F.: Effects of drying and wetting on nonlinear decay of soil shear strength in slope disintegration erosion area, Transactions of the Chinese Society of Agricultural Engineering, 28, 241-245, 2012 (in Chinese).
Zhong, B. L., Peng, S. Y., Zhang, Q., Ma, H., and Gao, S. X.: Using an ecological economics approach to support the restoration of collapsing gullies in southern China, Land Use Policy, 32, 119124, 2013.

Zhuang, Y. T., Huang, Y. H., Lin, J. S., Jiang, F. S., Zheng, Y., and Sun, S. X., Ding, Z. Q., and Yang, Y.: Study on liquid limit and plastic limit characteristics and factors of Benggang in red soil layer, Res. Soil Water Conserv., 21, 208-216, 2014 (in Chinese).

Zolfaghari, Z., Mosaddeghi, M. R., Ayoubi, S., and Kelishadi, H.: Soil Atterberg limits and consistency indices as influenced by land use and slope position in western Iran, J. Mt. Sci.-Engl., 12, 1471-1483, 2015. 